Наташа Станковић Шошо

УДК 378.6.096:811.163.41(497.11 БЕОГРАД)

natasoso06@gmail.com

371.3::821.163.41

Валентина Илић

vlil@ymail.com

Универзитет у Београду

Филолошки факултет

\title{
НАСТАВА МЕТОДИКЕ СРПСКОГ ЈЕЗИКА И КЊИЖЕВНОСТИ НА ФИЛОЛОШКОМ ФАКУЛТЕТУ УНИВЕРЗИТЕТА У БЕОГРАДУ ${ }^{1}$
}

У раду се указује на посебности проучавања обавезних и изборних методичких предмета на основним и мастер академским студијама на Катедри за српски језик са јужнословенским језицима и Катедри за српску књижевност са јужнословенским књижевностима Филолошког факултета Универзитета у Београду. Уз опис садржаја курсева, намењених студентима треће и четврте године, група 01 (Српски језик и књижевност), 05 (Српска књижевност и језик) и 06 (Српска књижевност и језик са компаратистиком), образлажу се најзначајнији циљеви и исходи универзитетске наставе и облици рада са студентима који се оспособљавају за професију наставника српског језика и књижевности у основној школи, гимназији и средњој стручној школи. Указује се на разноврсност тема Завршних радова из Методике наставе књижевности и српског језика на основним академским студијама и Завршних мастер радова из Методике наставе српског језика и књижевности на мастер академским студијама.

Кључне речи: методика, српски језик и књижевност, настава, факултет, студенти.

Обавезни и изборни предмети из Методике наставе књижевности и српског језика на основним и мастер академским студијама на Катедри за српску књижевност са јужнословенским књижевностима Филолошког факултета Универзитета у Београду

Методику наставе српског језика и књижевности на Филолошком факултету засновали су у другој половини 20. века проф.

${ }^{1}$ Рад представља резултат истраживања спроведеног у оквиру пројекта Cpnски језик и юегови ресурси: теорија, опис и примене, бр. 178006, који финансира Министарство просвете, науке и технолошког развоја Републике Србије. 
др Милија Николић² и проф. др Милорад Дешић, а током вишедеценијског рада ова научна дисциплина се развијала и унапређивала захваљујући научном и наставном раду универзитетских професора и врсних методичара проф. др Љиљане Бајић, проф. др Зоне Мркаљ, проф. др Драгане Вељковић Станковић и проф. др Вељка Брборића.

Настава методичких предмета на основним академским студијама Катедре за српску књижевност са јужнословенским књижевностима на Филолошком факултету Универзитета у Београду изучава се као приоритетна научна област којом се студенти Српске књижевности и језика (група 05) и Српске књижевности и језика са компаратистиком (група 06) припремају да буду наставници српског језика и књижевности. Континуирано развијање и унапређивање педагошко-психолошких и стручних компетенција студената остварује се изучавањем обавезних методичких предмета током треће и четврте године основних академских студија и у петој години мастер академских студија. Студенти основних академских студија као обавезне предмете изучавају: Увод у Методику 05, Методику наставе књижевности, Методику наставе српског језика (студенти групе 05), Увод у Методику 06, Методику наставе књижевности и српског језика (студенти групе 06). Током четврте године студенти имају Методичку праксу 06 (7. семестар), Методичку праксу 05 (8. семестар) и хоспитују у београдским основним школама ${ }^{3}$ и гимназијама ${ }^{4} \mathrm{y}$

2 Проф. др Милија Николић поставља темељ изучавања методике као базичне научне и наставне области на Универзитету у Београду. Његова књига Методика наставе српског језика и книжевности је и данас уџбеник из којег студенти стичу важна знања о овој значајној научној дисциплини.

${ }^{3}$ Методичка пракса за студенте Катедре за српску књижевност са јужнословенским књижевностима дуги низ година успешно се реализује у сарадњи са професорима српског језика и књижевности у ОШ „Раде Кончар” (Драгана Николин Коларић, Јелена Петаковић), ОШ „Младост” (Душица Мињовић и Марта Анђелић), ОШ „Дринка Павловић” (Славица Хорват, Катарина Колаковић, Наташа Васић и Јоле Булатовић), у ОШ „Краљ Петар Први” (Верица Стајић, Весна Јовановић, Јулијана Брадић Ћоровић) и у ОШ „Јанко Веселиновић” (Данијела Милићевић) и ОШ „Вук Караџић” (Славка Јовановић, Снежана Костадиновић).

${ }^{4}$ Гимназије у којима обављамо стручну праксу и професори са којима имамо успешну сарадњу су: Девета гимназија „Михаило Петровић Алас” (Светлана Ми- 
којима стичу своја прва наставна искуства и држе испитне часове из српског језика и књижевности.

Табела 1: Обавезни и изборни методички предмети на основним академским студијама на Катедри за српску књижевност и језик са јужнословенским књижевностима

\begin{tabular}{|c|c|c|c|}
\hline $\begin{array}{l}\text { III година } \\
\text { 5. семестар }\end{array}$ & $\begin{array}{l}\text { III година } \\
\text { 6. семестар }\end{array}$ & $\begin{array}{l}\text { IV година } \\
\text { 7. семестар }\end{array}$ & $\begin{array}{l}\text { IV година } \\
\text { 8. семестар }\end{array}$ \\
\hline $\begin{array}{l}\text { Увоg у Метиоgику } 05 \\
\text { (2 часа предавања и } \\
2 \text { часа семинарских } \\
\text { вежбања) } \\
6 \text { ЕСПБ } \\
\text { Наставници: проф. др } \\
\text { Љиљана Бајић, доц. } \\
\text { др Наташа Станковић } \\
\text { Шошо }\end{array}$ & $\begin{array}{l}\text { Метиояика настиаве } \\
\text { књижевносиии 05 } \\
\text { (2 часа предавања и } \\
2 \text { часа семинарских } \\
\text { вежбања) } \\
6 \text { ЕСПБ } \\
\text { Наставници: проф. } \\
\text { др Љиљана Бајић, } \\
\text { доц. др Наташа } \\
\text { Станковић Шошо }\end{array}$ & 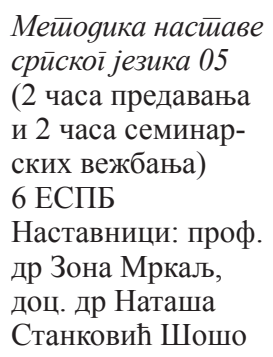 & $\begin{array}{l}\text { Метиояичка ирак- } \\
\text { са 05 } \\
6 \text { ЕСПБ } \\
\text { Наставници: } \\
\text { проф. др Зона } \\
\text { Мркаљ, доц. др } \\
\text { Наташа Станко- } \\
\text { вић Шошо }\end{array}$ \\
\hline $\begin{array}{l}\text { Увоg у Метеолику } 06 \\
\text { (2 часа предавања и } \\
2 \text { часа семинарских } \\
\text { вежбања) } \\
3 \text { ЕСПБ } \\
\text { Наставници: проф. } \\
\text { др Зона Мркаљ, доц. } \\
\text { др Наташа Станковић } \\
\text { Шошо }\end{array}$ & 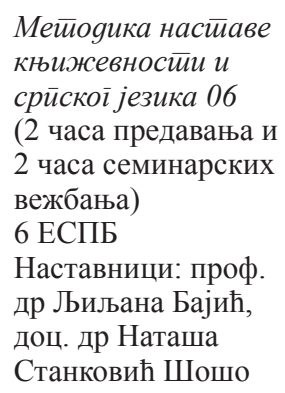 & $\begin{array}{l}\text { Мейояичка йрак- } \\
\text { са } 06 \\
6 \text { ЕСПБ }\end{array}$ & 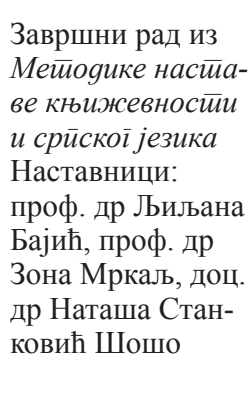 \\
\hline 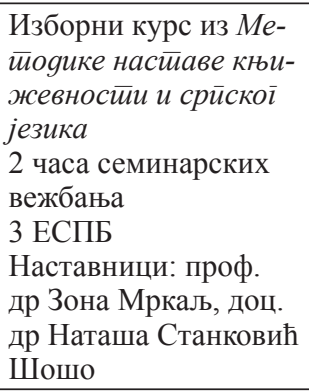 & & & \\
\hline
\end{tabular}

ловановић, Наталија Јовановић, Миланка Ршумовић, Драгана Петровић, Невена Грујичић, Ана Јокић, Милорад Дашић), Гимназија „Свети Сава” (Анђа Аландер, Јелена Ђорђевић, Сања Радосављевић), Филолошка гимназија (Мирјана Стакић Савковић, Лела Росић, Катарина Вучић, Татјана Жигић, Александра Кузмић) и Пета београдска гимназија (Милица Шаренац, Растко Јевтовић). 
Предметом Увод у Методику студенти стичу теоријска знања из опште методике, наставне методологије и дидактике. Програмски садржаји обухватају следеће наставне теме: предмет и задаци методике наставе српског језика и књижевности, однос методике наставе књижевности и српског језика према другим наукама, наставна методологија (обавештајне, логичке и стручне методе, методолошки плурализам и адекватност наставне методологије), наставни (дидактички) принципи (принцип научности и идејне усмерености наставе, принцип одмерености, принцип свесне активности, принцип повезивања теорије и праксе, принцип рационализације и економичности, принцип чулности, принцип поступности и систематичности, принцип индивидуализације), планирање у настави и наставниково припремање за извођење часова (врсте планирања и припремања, наставни план и програм), организација (структура) и врсте (типови) часова у настави, употреба наставних средства, облици рада (фронтални, индивидуални и групни рад), образовни, васпитни и функционални циљеви наставе српског језика и књижевности, вредновање (оцењивање) знања и умења ученика, ученичке слободне активности и стандарди квалитета уџбеника.

Програмски садржаји предмета Методика наставе књижевности обухватају: наставну обраду књижевног дела (појам, нивое обраде), методичке радње у проучавању књижевног текста (мотивисање ученика за читање, врсте читања (доживљајно, истраживачко, интерпретативно), истраживачке задатке и пројекте, локализовање текста, тумачење непознатих речи и израза, план текста, аналитичко-синтетичко проучавање књижевног дела), интеграционе чиниоце у тумачењу књижевног дела и адекватне методичке приступе жанровски разноврсним књижевним текстовима (тумачење народне лирске и ауторске лирске песме, обрада народне и ауторске приповетке и новеле, интерпретација приповедне збирке, романа, драме, проучавање епске народне песме, народне бајке и шаљиве приче). На семинарским вежбањима, према планираној динамици изучавања на предавањима, обрађују се књижевна дела различитих жанрова на одабраним текстовима који су у школском програму. Своја теоретска 
знања студенти примењују током писања детаљних методичких пројеката, који својим садржајем и структуром обликују процес инструктивног деловања наставника и активност ученика на часовима обраде наставних јединица из књижевности и српског језика. Они настоје да на поуздан начин систематично истражују, анализирају и усмеравају функционално припремање ученика за стваралачку наставу књижевности и српског језика у основној и средњој школи. С посебном пажњом студенти сагледавају адекватне наставне циљеве, поступке мотивисања, планирају одговарајуће врсте читања и пишу задатке за истраживачко читање књижевних текстова. Локализовање текста и вантекстовни чиниоци, укључују се по потреби, на начин који истиче њихову значајну улогу у развијању истраживачких способности, сазнајних активности ученика и интерпретације књижевног дела у настави. На часовима семинарских вежбања посебна пажња се посвећује анализи језика и стила у књижевном делу, као и естетским, идејним и етичким вредностима текста.

Предмет Методика наставе књижевности и српског јези$\kappa a$ уз описане наставне садржаје обухвата и методолошко повезивање и обједињавање наставе књижевности и српског језика, функционалне поступке у обради граматике, ортоепије и правописа; облике рада у неговању говорне културе и писмености (говорне и писмене вежбе и састави) и проблемску, истраживачку и стваралачку наставу српског језика. На часовима семинарских вежбања континуирано се повезује градиво из српског језика (граматика, правопис, ортоепија) и језичке културе (усмено и писано изражавање) са наставом књижевности. Основна полазишта у настави овог предмета јесу: повезивање свих области и подобласти предмета српски језик (књижевност, граматика, правопис, ортоепија и култура изражавања).

Методика наставе српског језика обухвата следеће наставне садржаје: методолошко повезивање наставе матерњег језика и књижевности; коришћење књижевноуметничких и научнопопуларних текстова у настави граматике и стилистике; наставни циљеви усмерени ка реализацији садржаја из граматике, ортоепије, правописа и језичке културе; методичке радње у обра- 
ди наставних јединица из српског језика; формирање задатака и структурирање иницијалних, полугодишњих и годишњих тестова из граматике; систематски и континуиран рад у настави писмености; функционални поступци у настави граматике; облици рада у неговању говорне културе и писмености (говорне и писмене вежбе и састави), допунски и додатни рад у настави српског језика и слободне активности ученика (новинарска, рецитаторска, драмска, лингвистичка, литерарна секција).

Стечена теоријска знања из Методике наставе књижевности и српског језика, студенти на продуктиван, истраживачки и стваралачки начин примењују у четвртој години приликом припремања и реализације наставних часова у основној и средњој школи. На предметима Методичка пракса 05 и Методичка пракса 06 студенти се обучавају да уз уважавање дидактичких принципа и проверене наставне методологије своја стручна знања и умења из књижевности и српског језика на функционални, истраживачки и стваралачки начин примењују. Након уводних часова предавања и вежбања на почетку семестра, студенти се упућују на хоспитовање у основне школе и гимназије у којима присуствују на осамнаест часова (9 часова у основној школи и 9 часова у гимназији). Хоспитовање у основној школи и гимназији се реализује у новембру у 7. семестру и марту у 8. семестру, а према распореду наставника на чијим часовима студенти присуствују. Током хоспитовања у школи, студенти воде Дневник хоспитовања у којем бележе запажања о одржаним часовима. Посредством Дневника хоспитовањ а стиче се увид у индивидуални рад студента на хоспитовању (праћење часа, стручна запажања и коментари, упознавање конкретних наставних околности и планирање начина на које ће се они уважавати приликом израде писане припреме и реализације наставног часа, стручна процена наставних ситуација). Последњег дана хоспитовања студенти добијају назив наставне јединице коју ће обрађивати као испитни час са ученицима следећег месеца. Писању методичке припреме за реализацију часа у школи посвећује се посебна пажња на индивидуалним консултацијама наставника и сарадника са студентом. Током индивидуалних консултација поводом израде методичке припреме студент 
износи концепт и замисао методичке припреме, отклања стручне недоумице, тражи и добија савете за рад, литературу и неопходну помоћ у виду стручних сугестија о изради методичке припреме и стручне сугестије о начину уважавања елемената у припреми, а који су важни за реализацију испитног часа. Консултације са студентима обухватају: индивидуалне консултације поводом израде методичке припреме, консултације поводом оцене и вредновања методичке припреме и индивидуалне консултације у вези са припремом за реализацију наставног часа. Испитном часу присуствује, уз наставника из школе, наставник на предмету или асистент. Реализацијом испитног часа и разговором о одржаном часу студенти остварују предиспитне обавезе из овог предмета.

Осим обавезних методичких предмета, студенти књижевности имају могућност да у 6. семестру бирају изборни курс из Методике наставе књижевности и српског језика, који у тежишту изучавања има облике рада подстакнуте књижевним текстом и стваралачке активности у настави српског језика и књижевности. Циљ изборног курса јесте да студенте упозна са истраживачком и стваралачком природом наставе књижевности која се заснива и развија у садејству теоријских и практичних достигнућа.

Студенти Катедре за српску књижевност са јужнословенским књижевностима имају дипломски испит који се састоји из израде Завршног рада из књижевности или Методике наставе књижевности и српског језика и образлагања резултата рада на усменој одбрани. У периоду од 2014. до 2019. године на Катедри за српску књижевност са јужнословенским књижевностима Завршни рад из Методике наставе књижевности и српског језика одбранило је 65 студената групе 05 и 06.

Табела 2: Одбрањени Завршни радови из Методике наставе књижевности и српског језика (2014-2019)

\begin{tabular}{|c|l|l|l|c|}
\hline \multicolumn{1}{|c|}{ Наслов рада } & \multicolumn{1}{|c|}{ Кандидат } & \multicolumn{1}{|c|}{$\begin{array}{c}\text { Комисија } \\
\text { (ментор и члан) }\end{array}$} & $\begin{array}{c}\text { Датум } \\
\text { одбране }\end{array}$ \\
\hline $\begin{array}{l}\text { Методички } \\
\text { приступ роману } \\
\text { „Зона Замфирова” } \\
\text { Стевана Сремца }\end{array}$ & $\begin{array}{l}\text { Злата } \\
\text { Петровић }\end{array}$ & $\begin{array}{l}\text { Зона Мркаљ, Наташа } \\
\text { Станковић Шошо }\end{array}$ & 16.1 .2014$. \\
\hline
\end{tabular}




\begin{tabular}{|c|c|c|c|}
\hline $\begin{array}{l}\text { Мотив моста } \\
\text { као кључни } \\
\text { интеграциони } \\
\text { чинилац наставне } \\
\text { интерпретације } \\
\text { у одабраним } \\
\text { Андрићевим } \\
\text { делима }\end{array}$ & Милица Коцић & $\begin{array}{l}\text { Зона Мркаљ, Наташа } \\
\text { Станковић Шошо }\end{array}$ & 4. 2. 2014 . \\
\hline $\begin{array}{l}\text { Стваралаштво } \\
\text { Вељка Петровића у } \\
\text { настави }\end{array}$ & $\begin{array}{l}\text { Виолета } \\
\text { Миковић }\end{array}$ & $\begin{array}{l}\text { Зона Мркаљ, Наташа } \\
\text { Станковић Шошо }\end{array}$ & 5. 2. 2014 \\
\hline $\begin{array}{l}\text { Поезија Бранка } \\
\text { Миљковића у } \\
\text { средњошколској } \\
\text { настави }\end{array}$ & $\begin{array}{l}\text { Александра } \\
\text { Савић }\end{array}$ & $\begin{array}{l}\text { Зона Мркаљ, Наташа } \\
\text { Станковић Шошо }\end{array}$ & 5. 2. 2014 \\
\hline $\begin{array}{l}\text { Методички приступ } \\
\text { роману „Кад су } \\
\text { цветале тикве” Д. } \\
\text { Михајловића }\end{array}$ & $\begin{array}{l}\text { Невена } \\
\text { Милићевић }\end{array}$ & $\begin{array}{l}\text { Зона Мркаљ, Наташа } \\
\text { Станковић Шошо }\end{array}$ & 12. 2. 2014 . \\
\hline $\begin{array}{l}\text { Учење граматике у } \\
\text { старији разредима } \\
\text { основне школе }\end{array}$ & Ана Рњаковић & $\begin{array}{l}\text { Зона Мркаљ, Наташа } \\
\text { Станковић Шошо }\end{array}$ & 14. 2. 2014 . \\
\hline $\begin{array}{l}\text { Поезија Јована } \\
\text { Дучића у настави } \\
\text { српског језика и } \\
\text { књижевности }\end{array}$ & Јелена Тошић & $\begin{array}{l}\text { Зона Мркаљ, Наташа } \\
\text { Станковић Шошо }\end{array}$ & 5. 6. 2014. \\
\hline $\begin{array}{l}\text { Методички приступ } \\
\text { делу „Рани јади” } \\
\text { Данила Киша }\end{array}$ & $\begin{array}{l}\text { Светлана } \\
\text { Јовановић }\end{array}$ & $\begin{array}{l}\text { Зона Мркаљ, Љиљана } \\
\text { Бајић, Наташа Станковић } \\
\text { Шошо }\end{array}$ & 5. 6. 2014. \\
\hline $\begin{array}{l}\text { Методички приступ } \\
\text { епским народним } \\
\text { песмама у основној } \\
\text { школи }\end{array}$ & Јелена Даблин & $\begin{array}{l}\text { Зона Мркаљ, Љиљана } \\
\text { Бајић, Наташа Станковић } \\
\text { Шошо }\end{array}$ & 5. 6. 2014. \\
\hline $\begin{array}{l}\text { Наставна } \\
\text { интерпретација } \\
\text { сатиричних } \\
\text { приповедака Радоја } \\
\text { Домановића }\end{array}$ & $\begin{array}{l}\text { Ђурђа } \\
\text { Живковић }\end{array}$ & $\begin{array}{l}\text { Зона Мркаљ, Наташа } \\
\text { Станковић Шошо }\end{array}$ & 18. 6. 2014. \\
\hline $\begin{array}{l}\text { Поезија Јована } \\
\text { Јовановића Змаја у } \\
\text { настави }\end{array}$ & Маја Ћубић & $\begin{array}{l}\text { Зона Мркаљ, Наташа } \\
\text { Станковић Шошо }\end{array}$ & 18. 6. 2014. \\
\hline $\begin{array}{l}\text { Проблемски } \\
\text { приступ тумачењу } \\
\text { одабраних } \\
\text { књижевних ликова } \\
\text { у Андрићевом делу }\end{array}$ & $\begin{array}{l}\text { Јована } \\
\text { Дмитрић }\end{array}$ & $\begin{array}{l}\text { Зона Мркаљ, Наташа } \\
\text { Станковић Шошо }\end{array}$ & 18. 7. 2014. \\
\hline
\end{tabular}




\begin{tabular}{|c|c|c|c|c|}
\hline & $\begin{array}{l}\text { Методички приступ } \\
\text { збирци „Из тамног } \\
\text { вилајета” Момчила } \\
\text { Настасијевића } \\
\text { (могућ наставни } \\
\text { приступ за четврти } \\
\text { разред гимназија и } \\
\text { средњих стручних } \\
\text { школа) }\end{array}$ & $\begin{array}{l}\text { Милица } \\
\text { Камајић }\end{array}$ & $\begin{array}{l}\text { Зона Мркаљ, Наташа } \\
\text { Станковић Шошо }\end{array}$ & 18. 7. 2014. \\
\hline & $\begin{array}{l}\text { Одабрана дела } \\
\text { Ивана Цанкара у } \\
\text { настави } \\
\end{array}$ & $\begin{array}{l}\text { Драгана } \\
\text { Обрадовић }\end{array}$ & $\begin{array}{l}\text { Зона Мркаљ, Љиљана } \\
\text { Бајић, Наташа Станковић } \\
\text { Шошо } \\
\end{array}$ & 11. 9. 2014. \\
\hline & $\begin{array}{l}\text { Васпитна } \\
\text { улога наставе } \\
\text { књижевности и } \\
\text { српског језика }\end{array}$ & $\begin{array}{l}\text { Невена } \\
\text { Глигоријевић }\end{array}$ & $\begin{array}{l}\text { Зона Мркаљ, Љиљана } \\
\text { Бајић, Наташа Станковић } \\
\text { Шошо }\end{array}$ & 11. 9. 2014. \\
\hline & $\begin{array}{l}\text { Методички приступ } \\
\text { делу Милоша } \\
\text { Црњанског у } \\
\text { основној школи }\end{array}$ & $\begin{array}{l}\text { Катарина } \\
\text { Миликијев }\end{array}$ & $\begin{array}{l}\text { Зона Мркаљ, Љиљана } \\
\text { Бајић, Наташа Станковић } \\
\text { Шошо }\end{array}$ & 11. 9. 2014. \\
\hline & $\begin{array}{l}\text { Креативно писање } \\
\text { у настави }\end{array}$ & $\begin{array}{l}\text { Ана Марија } \\
\text { Грбић }\end{array}$ & $\begin{array}{l}\text { Зона Мркаљ, Љиљана } \\
\text { Бајић, Наташа Станковић } \\
\text { Шошо }\end{array}$ & 11. 9. 2014. \\
\hline & $\begin{array}{l}\text { Српска средњове- } \\
\text { ковна књижевност } \\
\text { у настави }\end{array}$ & Нина Шуша & $\begin{array}{l}\text { Зона Мркаљ, Наташа } \\
\text { Станковић Шошо }\end{array}$ & 30.9. 2014. \\
\hline & $\begin{array}{l}\text { Поезија Владислава } \\
\text { Петковића Диса у } \\
\text { настави }\end{array}$ & $\begin{array}{l}\text { Милица } \\
\text { Јоксимовић }\end{array}$ & $\begin{array}{l}\text { Зона Мркаљ, Љиљана } \\
\text { Бајић, Наташа Станковић } \\
\text { Шошо }\end{array}$ & 30. 9. 2014. \\
\hline & $\begin{array}{l}\text { Задаци за } \\
\text { истраживачко } \\
\text { читање у настави }\end{array}$ & $\begin{array}{l}\text { Марина } \\
\text { Недовић }\end{array}$ & $\begin{array}{l}\text { Зона Мркаљ, Љиљана } \\
\text { Бајић, Наташа Станковић } \\
\text { Шошо }\end{array}$ & $\begin{array}{l}10.10 \text {. } \\
2014 .\end{array}$ \\
\hline & $\begin{array}{l}\text { Обрада Андрићеве } \\
\text { приповетке „Аска и } \\
\text { вук” на различитим } \\
\text { школским } \\
\text { узрастима }\end{array}$ & $\begin{array}{l}\text { Александра } \\
\text { Данилов }\end{array}$ & $\begin{array}{l}\text { Зона Мркаљ, Љиљана } \\
\text { Бајић, Наташа Станковић } \\
\text { Шошо }\end{array}$ & $\begin{array}{l}10.10 . \\
2014 .\end{array}$ \\
\hline \multirow[t]{2}{*}{2015.} & $\begin{array}{l}\text { Инклузивно } \\
\text { образовање } \\
\text { у настави } \\
\text { српског језика и } \\
\text { књижевности }\end{array}$ & $\begin{array}{l}\text { Марија } \\
\text { Миљић }\end{array}$ & $\begin{array}{l}\text { Зона Мркаљ, Љиљана } \\
\text { Бајић, Наташа Станковић } \\
\text { Шошо }\end{array}$ & 2. 2. 2015 . \\
\hline & $\begin{array}{l}\text { Обрада драмског } \\
\text { текста у настави } \\
\text { („Сабирни } \\
\text { центар” Душана } \\
\text { Ковачевића) }\end{array}$ & Ивана Митић & $\begin{array}{l}\text { Зона Мркаљ, Љиљана } \\
\text { Бајић, Наташа Станковић } \\
\text { Шошо }\end{array}$ & 8. 6. 2015 . \\
\hline
\end{tabular}




\begin{tabular}{|c|c|c|c|c|}
\hline & $\begin{array}{l}\text { Наставно } \\
\text { проучавање романа } \\
\text { „Робинзон Крусо” } \\
\text { Данијела Дефоа }\end{array}$ & Марија Димић & $\begin{array}{l}\text { Зона Мркаљ, Наташа } \\
\text { Станковић Шошо }\end{array}$ & 7. 7. 2015 . \\
\hline & $\begin{array}{l}\text { Заснивање } \\
\text { проблемског } \\
\text { приступа у настави } \\
\text { српског језика и } \\
\text { књижевности }\end{array}$ & $\begin{array}{l}\text { Дуња } \\
\text { Бранковић }\end{array}$ & $\begin{array}{l}\text { Зона Мркаљ, Љиљана } \\
\text { Бајић, Наташа Станковић } \\
\text { Шошо }\end{array}$ & 30.9. 2015. \\
\hline & $\begin{array}{l}\text { Наставно } \\
\text { проучавање поезије } \\
\text { Ивана В. Лалића }\end{array}$ & $\begin{array}{l}\text { Александра } \\
\text { Живковић }\end{array}$ & $\begin{array}{l}\text { Зона Мркаљ, Љиљана } \\
\text { Бајић, Наташа Станковић } \\
\text { Шошо }\end{array}$ & 30.9. 2015. \\
\hline & $\begin{array}{l}\text { Наставна обрада } \\
\text { романа „Робинзон } \\
\text { Крусо” Данијела } \\
\text { Дефоа }\end{array}$ & Неда Гогић & $\begin{array}{l}\text { Зона Мркаљ, Наташа } \\
\text { Станковић Шошо }\end{array}$ & 30.9. 2015. \\
\hline \multirow[t]{6}{*}{2016.} & $\begin{array}{l}\text { Наставно } \\
\text { проучавање } \\
\text { поезије Владислава } \\
\text { Петковића Диса }\end{array}$ & Ива Златић & $\begin{array}{l}\text { Зона Мркаљ, Наташа } \\
\text { Станковић Шошо }\end{array}$ & 20.1. 2016 . \\
\hline & $\begin{array}{l}\text { Наставно тумачење } \\
\text { одабране поезије у } \\
\text { јужнословенском } \\
\text { контексту }\end{array}$ & $\begin{array}{l}\text { Љиљана Б. } \\
\text { Божић }\end{array}$ & $\begin{array}{l}\text { Зона Мркаљ, Наташа } \\
\text { Станковић Шошо }\end{array}$ & 20. 1. 2016. \\
\hline & $\begin{array}{l}\text { Обрада романа } \\
\text { „Аутобиографија” } \\
\text { Бранислава } \\
\text { Нушића }\end{array}$ & $\begin{array}{l}\text { Марина } \\
\text { Јовановић }\end{array}$ & $\begin{array}{l}\text { Зона Мркаљ, Наташа } \\
\text { Станковић Шошо }\end{array}$ & 12. 2. 2016 . \\
\hline & $\begin{array}{l}\text { Улога игре } \\
\text { у настави } \\
\text { српског језика и } \\
\text { књижевности у } \\
\text { основној школи }\end{array}$ & Ивана Илић & $\begin{array}{l}\text { Зона Мркаљ, Наташа } \\
\text { Станковић Шошо }\end{array}$ & 14. 7. 2016. \\
\hline & $\begin{array}{l}\text { Наставно } \\
\text { проучавање } \\
\text { Нушићеве } \\
\text { комедије „Госпођа } \\
\text { министарка” у } \\
\text { средњој школи }\end{array}$ & Ана Ђорђевић & $\begin{array}{l}\text { Зона Мркаљ, Наташа } \\
\text { Станковић Шошо }\end{array}$ & 28. 9. 2016. \\
\hline & $\begin{array}{l}\text { Примена } \\
\text { фотографије } \\
\text { у настави } \\
\text { књижевности }\end{array}$ & $\begin{array}{l}\text { Ивана } \\
\text { Манојловић }\end{array}$ & $\begin{array}{l}\text { Зона Мркаљ, Наташа } \\
\text { Станковић Шошо }\end{array}$ & 5. 10. 2016. \\
\hline 2017. & $\begin{array}{l}\text { Наставни приступ } \\
\text { роману „Сеобе” } \\
\text { Милоша Црњан- } \\
\text { ског у основној и } \\
\text { средњој школи }\end{array}$ & $\begin{array}{l}\text { Љубица } \\
\text { Георгијев }\end{array}$ & $\begin{array}{l}\text { Зона Мркаљ, Наташа } \\
\text { Станковић Шошо }\end{array}$ & 18. 2. 2017. \\
\hline
\end{tabular}


Наташа Станковић Шошо, Валентина Илић

\begin{tabular}{|c|c|c|c|c|}
\hline & $\begin{array}{l}\text { Рецепција романа } \\
\text { „Хазарски речник” } \\
\text { Милорада Павића }\end{array}$ & $\begin{array}{l}\text { Тијана } \\
\text { Дрндарски }\end{array}$ & $\begin{array}{l}\text { Зона Мркаљ, Наташа } \\
\text { Станковић Шошо }\end{array}$ & 19. 4. 2017. \\
\hline & $\begin{array}{l}\text { Наставно тумачење } \\
\text { „Ех Роnta” И. } \\
\text { Андрића }\end{array}$ & Виолета Себић & $\begin{array}{l}\text { Зона Мркаљ, Наташа } \\
\text { Станковић Шошо }\end{array}$ & 7. 6. 2017. \\
\hline & $\begin{array}{l}\text { Дучићеви путописи } \\
\text { у корелацији са } \\
\text { другим наставним } \\
\text { садржајима }\end{array}$ & $\begin{array}{l}\text { Александра } \\
\text { Данилов }\end{array}$ & $\begin{array}{l}\text { Зона Мркаљ, Наташа } \\
\text { Станковић Шошо }\end{array}$ & 11. 7. 2017. \\
\hline & $\begin{array}{l}\text { Проблем } \\
\text { луталаштва у } \\
\text { Кишовој трилогији } \\
\end{array}$ & $\begin{array}{l}\text { Јелена } \\
\text { Медаковић }\end{array}$ & $\begin{array}{l}\text { Зона Мркаљ, Наташа } \\
\text { Станковић Шошо }\end{array}$ & 11. 7. 2017. \\
\hline & $\begin{array}{l}\text { 5. Проучавање } \\
\text { лирских песама у } \\
\text { настави на примеру } \\
\text { поезије Антуна } \\
\text { Густава Матоша и } \\
\text { Јована Дучића }\end{array}$ & $\begin{array}{l}\text { Софија } \\
\text { Симовић }\end{array}$ & $\begin{array}{l}\text { Наташа Станковић } \\
\text { Шошо, Љиљана Бајић }\end{array}$ & 20.9. 2017. \\
\hline & $\begin{array}{l}\text { Драма Коштана } \\
\text { Борисава } \\
\text { Станковића у } \\
\text { корелацији са } \\
\text { наставним и } \\
\text { ваннаставним } \\
\text { активностима }\end{array}$ & Драгана Илић & $\begin{array}{l}\text { Зона Мркаљ, Наташа } \\
\text { Станковић Шошо }\end{array}$ & 28. 9. 2017. \\
\hline & $\begin{array}{l}\text { Методичка обрада } \\
\text { приповетке } \\
\text { „У ноћи” Б. } \\
\text { Станковића }\end{array}$ & Анета Ракиџић & $\begin{array}{l}\text { Зона Мркаљ, Наташа } \\
\text { Станковић Шошо }\end{array}$ & 28. 9. 2017. \\
\hline & $\begin{array}{l}\text { Поезија Војислава } \\
\text { Илића у настави } \\
\text { књижевности }\end{array}$ & $\begin{array}{l}\text { Велибор } \\
\text { Пуповић }\end{array}$ & $\begin{array}{l}\text { Зона Мркаљ, Наташа } \\
\text { Станковић Шошо }\end{array}$ & 30. 9. 2017. \\
\hline \multirow[t]{3}{*}{2018.} & $\begin{array}{l}\text { Наставна обрада } \\
\text { синтагми у } \\
\text { основној школи }\end{array}$ & $\begin{array}{l}\text { Бојана } \\
\text { Милосављевић }\end{array}$ & $\begin{array}{l}\text { Наташа Станковић } \\
\text { Шошо, Зона Мркаљ }\end{array}$ & 23. 2. 2018. \\
\hline & $\begin{array}{l}\text { Мапе ума у } \\
\text { настави српског } \\
\text { језика и } \\
\text { књижевности }\end{array}$ & $\begin{array}{l}\text { Драгана } \\
\text { Вуканац }\end{array}$ & $\begin{array}{l}\text { Зона Мркаљ, Наташа } \\
\text { Станковић Шошо }\end{array}$ & 20. 4. 2018 . \\
\hline & $\begin{array}{l}\text { Наставна } \\
\text { интерпретација } \\
\text { „Сеоба” Милоша } \\
\text { Црњанског у } \\
\text { основној и средњој } \\
\text { школи }\end{array}$ & $\begin{array}{l}\text { Емилија } \\
\text { Пандоски }\end{array}$ & $\begin{array}{l}\text { Зона Мркаљ, Наташа } \\
\text { Станковић Шошо }\end{array}$ & 14. 6. 2018 . \\
\hline
\end{tabular}




\begin{tabular}{|c|c|c|c|c|}
\hline & $\begin{array}{l}\text { Проучавање } \\
\text { приповедне прозе у } \\
\text { настави на примеру } \\
\text { приче „Чекање” X. } \\
\text { Л. Борхеса }\end{array}$ & $\begin{array}{l}\text { Невена } \\
\text { Лукинић }\end{array}$ & $\begin{array}{l}\text { Наташа Станковић } \\
\text { Шошо, Љиљана Бајић }\end{array}$ & 6. 9. 2018. \\
\hline & $\begin{array}{l}\text { Методичка обрада } \\
\text { Дисових песама } \\
\text { „Тамница”, } \\
\text { „Нирвана” и } \\
\text { „Можда спава” }\end{array}$ & Маша Тадић & $\begin{array}{l}\text { Зона Мркаљ, Наташа } \\
\text { Станковић Шошо }\end{array}$ & 10.9. 2018. \\
\hline & $\begin{array}{l}\text { Структура „Госпође } \\
\text { министарке” } \\
\text {-интерпретацијске } \\
\text { могућности } \\
\text { антанцијалне } \\
\text { анализе у настави } \\
\text { књижевности }\end{array}$ & $\begin{array}{l}\text { Сандра } \\
\text { Величковић }\end{array}$ & $\begin{array}{l}\text { Наташа Станковић } \\
\text { Шошо, Драгана } \\
\text { Вукићевић }\end{array}$ & 12. 9. 2018. \\
\hline & $\begin{array}{l}\text { Интерпретација } \\
\text { романа „Дервиш } \\
\text { и смрт” М. } \\
\text { Селимовића }\end{array}$ & $\begin{array}{l}\text { Катарина } \\
\text { Стојановић }\end{array}$ & $\begin{array}{l}\text { Наташа Станковић } \\
\text { Шошо, Љиљана Бајић }\end{array}$ & 24. 9. 2018. \\
\hline & $\begin{array}{l}\text { Наставно } \\
\text { проучавање } \\
\text { приповетке } \\
\text { „Све ће то народ } \\
\text { позлатити” Л. } \\
\text { Лазаревића у } \\
\text { основној школи }\end{array}$ & Тина Поповић & $\begin{array}{l}\text { Наташа Станковић } \\
\text { Шошо, Зона Мркаљ }\end{array}$ & 24. 9. 2018. \\
\hline & $\begin{array}{l}\text { Проучавање } \\
\text { народних } \\
\text { приповедака у } \\
\text { основној школи }\end{array}$ & Јана Шоћ & $\begin{array}{l}\text { Наташа Станковић } \\
\text { Шошо, Зона Мркаљ }\end{array}$ & 27. 9. 2018. \\
\hline & $\begin{array}{l}\text { Методичка } \\
\text { припрема за } \\
\text { обраду романа } \\
\text { „Сеобе” Милоша } \\
\text { Црњанског у } \\
\text { основној школи }\end{array}$ & $\begin{array}{l}\text { Кристина } \\
\text { Петровић }\end{array}$ & $\begin{array}{l}\text { Наташа Станковић } \\
\text { Шошо, Љиљана Бајић }\end{array}$ & 27. 9. 2018. \\
\hline & $\begin{array}{l}\text { Андрићеве приче } \\
\text { о деци у наставној } \\
\text { обради }\end{array}$ & $\begin{array}{l}\text { Николина } \\
\text { Растовић }\end{array}$ & $\begin{array}{l}\text { Зона Мркаљ, Наташа } \\
\text { Станковић Шошо }\end{array}$ & 27. 9. 2018. \\
\hline 2019. & $\begin{array}{l}\text { Наставна обрада } \\
\text { романа „Странац” } \\
\text { А. Камија }\end{array}$ & $\begin{array}{l}\text { Марјана } \\
\text { Калинић }\end{array}$ & $\begin{array}{l}\text { Наташа Станковић } \\
\text { Шошо, Љиљана Бајић }\end{array}$ & 13. 2. 2019. \\
\hline
\end{tabular}




\begin{tabular}{|c|c|c|c|}
\hline $\begin{array}{l}\text { Наставно } \\
\text { проучавање } \\
\text { приповедака Радоја } \\
\text { Домановића у } \\
\text { школи }\end{array}$ & $\begin{array}{l}\text { Катарина } \\
\text { Пајић }\end{array}$ & $\begin{array}{l}\text { Наташа Станковић } \\
\text { Шошо, Љиљана Бајић }\end{array}$ & 12. 7. 2019. \\
\hline $\begin{array}{l}\text { Наставна обрада } \\
\text { комедије „Сумњиво } \\
\text { лице” Б. Нушића у } \\
\text { основној школи }\end{array}$ & Милош Пешут & $\begin{array}{l}\text { Наташа Станковић } \\
\text { Шошо, Љиљана Бајић }\end{array}$ & 4. 9. 2019. \\
\hline $\begin{array}{l}\text { Наставно } \\
\text { проучавање збирке } \\
\text { приповедне прозе } \\
\text { „Башта сљезове } \\
\text { боје” Бранка } \\
\text { Һопића }\end{array}$ & $\begin{array}{l}\text { Софија } \\
\text { Тричковић }\end{array}$ & $\begin{array}{l}\text { Наташа Станковић } \\
\text { Шошо, Љиљана Бајић }\end{array}$ & 4. 9. 2019 . \\
\hline $\begin{array}{l}\text { Наставна обрада } \\
\text { приповедака } \\
\text { „Пилипенда” и } \\
\text { „Поварета” Симе } \\
\text { Матавуља }\end{array}$ & $\begin{array}{l}\text { Кристина } \\
\text { Милановић }\end{array}$ & $\begin{array}{l}\text { Наташа Станковић } \\
\text { Шошо, Љиљана Бајић }\end{array}$ & 20. 9. 2019. \\
\hline $\begin{array}{l}\text { Компаративни } \\
\text { приступ поетским } \\
\text { текстовима „Волео } \\
\text { сам Вас” А. С. } \\
\text { Пушкина и „Врт” } \\
\text { Ж. Превера у } \\
\text { настави }\end{array}$ & Филип Јешић & $\begin{array}{l}\text { Наташа Станковић } \\
\text { Шошо, Љиљана Бајић }\end{array}$ & 20.9. 2019. \\
\hline $\begin{array}{l}\text { Наставна обрада } \\
\text { приповетке „Из } \\
\text { баршунастог } \\
\text { албума” Данила } \\
\text { Киша у средњој } \\
\text { школи }\end{array}$ & Јована Томић & $\begin{array}{l}\text { Наташа Станковић } \\
\text { Шошо, Љиљана Бајић }\end{array}$ & 20. 9. 2019. \\
\hline $\begin{array}{l}\text { Проучавање лирске } \\
\text { поезије у основној } \\
\text { школи на примеру } \\
\text { песама Јована } \\
\text { Дучића }\end{array}$ & $\begin{array}{l}\text { Иван } \\
\text { Анђелковић }\end{array}$ & $\begin{array}{l}\text { Наташа Станковић } \\
\text { Шошо, Љиљана Бајић }\end{array}$ & 25. 9. 2019. \\
\hline $\begin{array}{l}\text { Приповетке } \\
\text { Борисава } \\
\text { Станковића у } \\
\text { настави }\end{array}$ & $\begin{array}{l}\text { Ивана } \\
\text { Марјановић }\end{array}$ & $\begin{array}{l}\text { Наташа Станковић } \\
\text { Шошо, Љиљана Бајић }\end{array}$ & 25. 9. 2019. \\
\hline $\begin{array}{l}\text { Методички приступ } \\
\text { драми „Чекајући } \\
\text { Годоа” С. Бекета }\end{array}$ & Сања Пејовић & $\begin{array}{l}\text { Наташа Станковић } \\
\text { Шошо, Љиљана Бајић }\end{array}$ & 25. 9. 2019. \\
\hline
\end{tabular}




\begin{tabular}{|c|c|c|c|}
\hline $\begin{array}{l}\text { Наставна обрада } \\
\text { приповетке „У } \\
\text { ноћи” Борисава } \\
\text { Станковића у } \\
\text { гимназији и } \\
\text { средњој стручној } \\
\text { школи }\end{array}$ & $\begin{array}{l}\text { Катарина } \\
\text { Марковић }\end{array}$ & $\begin{array}{l}\text { Наташа Станковић } \\
\text { Шошо, Љиљана Бајић }\end{array}$ & 26. 9. 2019. \\
\hline $\begin{array}{l}\text { Наставни приступ } \\
\text { изучавању } \\
\text { реалистичке } \\
\text { приповетке у } \\
\text { другом разреду } \\
\text { средње школе }\end{array}$ & $\begin{array}{l}\text { Милица } \\
\text { Тимотић }\end{array}$ & $\begin{array}{l}\text { Зона Мркаљ, Наташа } \\
\text { Станковић Шошо }\end{array}$ & 26. 9. 2019. \\
\hline $\begin{array}{l}\text { Методички приступ } \\
\text { дескриптивним } \\
\text { текстовима у } \\
\text { основној школи }\end{array}$ & $\begin{array}{l}\text { Кристина } \\
\text { Петровић }\end{array}$ & $\begin{array}{l}\text { Зона Мркаљ, Наташа } \\
\text { Станковић Шошо }\end{array}$ & 26. 9. 2019. \\
\hline $\begin{array}{l}\text { Настава акцената у } \\
\text { основној школи }\end{array}$ & $\begin{array}{l}\text { Милена } \\
\text { Тодоровић }\end{array}$ & $\begin{array}{l}\text { Наташа Станковић } \\
\text { Шошо, Љиљана Бајић }\end{array}$ & 30. 9. 2019. \\
\hline $\begin{array}{l}\text { Наставна обрада } \\
\text { лирске песме } \\
\text { „Родна груда” Симе } \\
\text { Пандуровића }\end{array}$ & $\begin{array}{l}\text { Маја } \\
\text { Ковачевић }\end{array}$ & $\begin{array}{l}\text { Наташа Станковић } \\
\text { Шошо, Љиљана Бајић }\end{array}$ & 30. 9. 2019. \\
\hline
\end{tabular}

На основу анализе табела увиђа се да је највеће интересовање студената за писање методичких радова из књижевности (65 дипломских радова) док је само 4 рада из области Meтодике наставе српског језика. Најбројнији су радови у којима се обрађују наставне јединице из Српске књижевности 20. века (31 рад) и Српске књижевности 19. века (14 радова). Компаративном приступу у наставном проучавању књижевних текстова посвећена су 4 рада, обради књижевних дела из светске књижевности 5 радова, уопштеним методичким темама 6 радова, док су интерпретацији књижевних текстова из народне и средњовековне књижевности посвећена 2 рада.

Награда која носи име Миодрага Павловића додељује се на Катедри за српску књижевност са јужнословенским књижевностима од 2016. године студентима 05 и 06 групе за најбољи рад из Методике наставе књижевности и српског језика. Она је установљена са жељом да афирмише и истакне оригиналне и проверене резултате студената у области којом се професор мр Миодраг Па- 
вловић успешно бавио дуги низ година, радећи посебно на припреми/обуци студената за методику струке. Награду која носи његово име додељена је током 2016. и 2017. године следећим студентима:

- За наставно проучавање лирске поезије награђени су: Софија Симовић (Антун Густав Матош: Јесење вече, Noturno), Лидија Хорват (Владислав Петковић Дис: Можда спава), Младен Станић (Бранко Радичевић: Кад млидија умрети);

- За наставно проучавање приповедног текста награђени су: Милан Вурдеља (Јаков Игњатовић: Вечити младожења); Јована Сувајџић (Мрачајски прото Петра Кочића), Ивана Марјановић (Борисав Станковић: Уноћu), Ивана Пантелић (Гроздана Олујић: Седефна ружа);

- За наставно проучавање књижевних текстова из баштине опште књижевности награђени су: Вања Петровић (Легенда о nomony), Невена Лукинић (Хорхе Луис Борхес: Чекање) и Тијана Копривица (Антон Павлович Чехов: Чиновникова смрт);

- За обраду наставне јединице из граматике награђена је Бојана Милосављевић за рад Појам синтагме: именичке, придевске, прилошке и глаголске синтагме.

\section{Методика наставе књижевности}

\section{на мастер академским студијама}

Методика наставе књижевности на мастер студијама представља студијски програм којим се продубљују знања из методичке теорије и наставне методологије, посебно у подручју тема о читалачким компетенцијама и наставној обради књижевних жанрова. Студенти се подстичу да знања из области Методике наставе књижевности проширују у даљем самосталном истраживачком раду и тако стичу додатне научне и стручне компетенције за разумевање и поуздано тумачење књижевних жанрова, односно за њихово адекватно читање и вредновање. На мастер академским студијама Методика наставе књижевности је обавезни предмет који се изучава у 9. и 10. семестру. 
Табела 3: Методички предмети на мастер академским студијама на Катедри за српску књижевност и језик са јужнословенским књижевностима

\begin{tabular}{|c|c|}
\hline $\begin{array}{l}\text { V година } \\
\text { 9. семестар }\end{array}$ & $\begin{array}{l}\text { V година } \\
10 . \text { семестар }\end{array}$ \\
\hline 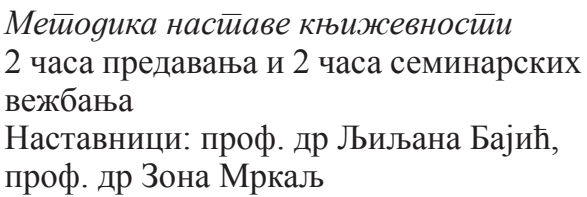 & 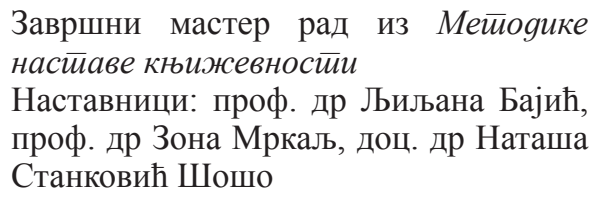 \\
\hline
\end{tabular}

Студенти на обавезном предмету Методика наставе књижевности имају по два часа предавања и семинарских вежбања на којима се на интезиван истраживачки начин у тимском раду проучавају и индивидуално истражују наставни садржаји из области књижевности (обрада књижевних жанрова на примерима усмених прозних облика и књижевног стваралаштва Б. Станковића). Садржаји предмета обухватају следеће наставне теме:

- специфичности проучавања народне и ауторске бајке у наставном контексту;

- улога жанра у формирању наставних интерпретација књижевноуметничког текста;

- методички поступци и радње у наставном проучавању књижевноуметничких текстова;

- језичкостилска анализа као обједињујући чинилац наставне интерпретације;

- компаративно проучавање усмених прозних облика;

- методички приступ збирци приповедне прозе;

- наставна интерпретација књижевноуметничког текста на различитим узрасним нивоима;

- развој читалачких компетенција;

- функционално повезивање наставе књижевности и матерњег језика;

- корелације у настави српског језика и књижевности.

У наставном раду се посебно подстичу облици и садржаји рада који омогућавају увид у књижевни текст и друге текстове култура и омогућавају примену поредбених гледишта у корелацијско-интеграцијском систему наставе. 
У периоду од 2014. до 2019. године 31 студент је успешно одбранио Завршни мастер рад из Методике наставе књижевности на Катедри за српску књижевност са јужнословенским књижевностима.

Табела 4: Одбрањени Завршни мастер радови из

Методике наставе књижевности и српског језика (2014-2019)

\begin{tabular}{|c|c|c|c|c|}
\hline & Наслов рада & Кандидат & $\begin{array}{c}\text { Комисија } \\
\text { (ментор и члан) }\end{array}$ & Датум одбране \\
\hline \multirow[t]{6}{*}{2014.} & $\begin{array}{l}\text { Проблемски приступ } \\
\text { малим фолклорним } \\
\text { формама }\end{array}$ & Марија Шљукић & $\begin{array}{l}\text { Зона Мркаљ, } \\
\text { Љиљана Бајић }\end{array}$ & 14. 2. 2014 . \\
\hline & $\begin{array}{l}\text { Посебности } \\
\text { наставног } \\
\text { проучавања народне } \\
\text { и ауторске бајке } \\
\text { на примеру бајке } \\
\text { „епељуга” }\end{array}$ & Марија Ђорђевић & $\begin{array}{l}\text { Зона Мркаљ, } \\
\text { Љиљана Бајић }\end{array}$ & 14. 2. 2014 . \\
\hline & $\begin{array}{l}\text { Делатност } \\
\text { новинарске секције } \\
\text { у основној и средњој } \\
\text { школи }\end{array}$ & Тамара Јарић & $\begin{array}{l}\text { Зона Мркаљ, } \\
\text { Љиљана } \\
\text { Бајић, Наташа } \\
\text { Станковић Шошо }\end{array}$ & 4. 9. 2014. \\
\hline & $\begin{array}{l}\text { Наставна тумачења } \\
\text { комедиографских } \\
\text { текстова у средњој } \\
\text { школи }\end{array}$ & Јована Јанковић & $\begin{array}{l}\text { Зона Мркаљ, } \\
\text { Љиљана } \\
\text { Бајић, Наташа } \\
\text { Станковић Шошо }\end{array}$ & 4. 9. 2014 . \\
\hline & $\begin{array}{l}\text { Језичко-стилска } \\
\text { анализа одломака } \\
\text { из романа „Сеобе” } \\
\text { Милоша Црњанског }\end{array}$ & $\begin{array}{l}\text { Владимир } \\
\text { Димитријевић }\end{array}$ & $\begin{array}{l}\text { Зона Мркаљ, } \\
\text { Љиљана } \\
\text { Бајић, Наташа } \\
\text { Станковић Шошо }\end{array}$ & 11. 10. 2014 \\
\hline & $\begin{array}{l}\text { Народна } \\
\text { књижевност у } \\
\text { контексту савремене } \\
\text { наставе }\end{array}$ & $\begin{array}{l}\text { Милица } \\
\text { Живковић }\end{array}$ & $\begin{array}{l}\text { Љиљана Бајић, } \\
\text { Зона Мркаљ, } \\
\text { Наташа } \\
\text { Станковић Шошо }\end{array}$ & 11. 10. 2014. \\
\hline \multirow[t]{2}{*}{2015.} & $\begin{array}{l}\text { Тумачење } \\
\text { романа у настави } \\
\text { српског језика и } \\
\text { књижевности }\end{array}$ & $\begin{array}{l}\text { Василиса } \\
\text { Ђуричић }\end{array}$ & $\begin{array}{l}\text { Зона Мркаљ, } \\
\text { Љиљана Бајић }\end{array}$ & 12. 2. 2015 . \\
\hline & $\begin{array}{l}\text { Обрада бајки } \\
\text { Тиодора Росића у } \\
\text { средњошколској } \\
\text { настави }\end{array}$ & $\begin{array}{l}\text { Никола } \\
\text { Продановић }\end{array}$ & $\begin{array}{l}\text { Зона Мркаљ, } \\
\text { Љиљана } \\
\text { Бајић, Наташа } \\
\text { Станковић Шошо }\end{array}$ & 9. 6.2015 . \\
\hline
\end{tabular}




\begin{tabular}{|c|c|c|c|c|}
\hline & $\begin{array}{l}\text { Мотив лепоте } \\
\text { у епским и } \\
\text { баладичним песмама } \\
\text { о женидби јунака } \\
\text { (наставни приступ) }\end{array}$ & $\begin{array}{l}\text { Катарина } \\
\text { Миликиев }\end{array}$ & $\begin{array}{l}\text { Зона Мркаљ, } \\
\text { Љиљана } \\
\text { Бајић, Наташа } \\
\text { Станковић Шошо }\end{array}$ & 9. 6. 2015 . \\
\hline & $\begin{array}{l}\text { Мултимедијални } \\
\text { приступ у настави } \\
\text { матерњег језика и } \\
\text { књижевности }\end{array}$ & Јелена Дабин & $\begin{array}{l}\text { Зона Мркаљ, } \\
\text { Љиљана } \\
\text { Бајић, Наташа } \\
\text { Станковић Шошо }\end{array}$ & 16.6.2015. \\
\hline & $\begin{array}{l}\text { Дело Јована Стерије } \\
\text { Поповића у настави } \\
\text { књижевности. }\end{array}$ & Маја Марјановић & $\begin{array}{l}\text { Зона Мркаљ, } \\
\text { Љиљана } \\
\text { Бајић, Наташа } \\
\text { Станковић Шошо }\end{array}$ & 29. 9. 2017. \\
\hline & $\begin{array}{l}\text { Циклус } \\
\text { приповедака „Сиво } \\
\text { трајање” Бранка } \\
\text { Ћопића у настави }\end{array}$ & $\begin{array}{l}\text { Драгана } \\
\text { Обрадовић }\end{array}$ & $\begin{array}{l}\text { Љиљана Бајић, } \\
\text { Зона Мркаљ, } \\
\text { Наташа } \\
\text { Станковић Шошо }\end{array}$ & 15.7.2015. \\
\hline & $\begin{array}{l}\text { Приручник за } \\
\text { ментора Креативног } \\
\text { писања }\end{array}$ & $\begin{array}{l}\text { Ана Марија } \\
\text { Грбић }\end{array}$ & $\begin{array}{l}\text { Љиљана Бајић, } \\
\text { Зона Мркаљ, } \\
\text { Наташа } \\
\text { Станковић Шошо }\end{array}$ & 29. 9. 2015. \\
\hline & $\begin{array}{l}\text { Збирка приповедне } \\
\text { прозе Данила } \\
\text { Киша у наставном } \\
\text { контексту }\end{array}$ & Дуња Марковић & $\begin{array}{l}\text { Љиљана } \\
\text { Бајић, Зона } \\
\text { Мркаљ, Наташа } \\
\text { Станковић Шошо }\end{array}$ & 29. 9. 2015. \\
\hline & $\begin{array}{l}\text { Примери наставног } \\
\text { проучавања романа } \\
\text { у Математичкој } \\
\text { гимназији }\end{array}$ & $\begin{array}{l}\text { Душица } \\
\text { Атанасковић }\end{array}$ & $\begin{array}{l}\text { Зона Мркаљ, } \\
\text { Љиљана } \\
\text { Бајић, Наташа } \\
\text { Станковић Шошо }\end{array}$ & 29.9.2015. \\
\hline \multirow[t]{4}{*}{2016.} & $\begin{array}{l}\text { Типови јунакиње } \\
\text { у ауторској бајци } \\
\text { Гроздане Олујић }\end{array}$ & $\begin{array}{l}\text { Зорица } \\
\text { Милинковић }\end{array}$ & $\begin{array}{l}\text { Зона Мркаљ, } \\
\text { Наташа } \\
\text { Станковић Шошо }\end{array}$ & 20.1. 2016 . \\
\hline & $\begin{array}{l}\text { Методички приступ } \\
\text { лирском циклусу } \\
\text { у наставном } \\
\text { проучавању }\end{array}$ & Дуња Бранковић & $\begin{array}{l}\text { Љиљана Бајић, } \\
\text { Зона Мркаљ, } \\
\text { Наташа } \\
\text { Станковић Шошо }\end{array}$ & 28. 9. 2016. \\
\hline & $\begin{array}{l}\text { Примена Фејсбука } \\
\text { у настави } \\
\text { српског језика и } \\
\text { књижевности }\end{array}$ & $\begin{array}{l}\text { Шана } \\
\text { Младеновић }\end{array}$ & $\begin{array}{l}\text { Зона Мркаљ, } \\
\text { Љиљана } \\
\text { Бајић, Наташа } \\
\text { Станковић Шошо }\end{array}$ & 5. 10. 2016. \\
\hline & $\begin{array}{l}\text { Књижевно дело } \\
\text { и компетенције } \\
\text { читаоца у } \\
\text { збирци „Вук и } \\
\text { звоно” Миодрага } \\
\text { Булатовића }\end{array}$ & $\begin{array}{l}\text { Ангелина } \\
\text { Смиљанић }\end{array}$ & $\begin{array}{l}\text { Зона Мркаљ, } \\
\text { Љиљана } \\
\text { Бајић, Наташа } \\
\text { Станковић Шошо }\end{array}$ & 5. 10. 2016. \\
\hline
\end{tabular}




\begin{tabular}{|c|c|c|c|c|}
\hline 2017. & $\begin{array}{l}\text { Приповедна } \\
\text { проза Драгослава } \\
\text { Михаиловића у } \\
\text { настави }\end{array}$ & Ивана Вуковић & $\begin{array}{l}\text { Зона Мркаљ, } \\
\text { Наташа } \\
\text { Станковић Шошо }\end{array}$ & 13. 7.2017. \\
\hline & $\begin{array}{l}\text { Тумачење српске } \\
\text { реалистичке } \\
\text { приповетке у оквиру } \\
\text { индивидуалног } \\
\text { образовног плана у } \\
\text { средњој школи }\end{array}$ & Бојана Лукић & $\begin{array}{l}\text { Зона Мркаљ, } \\
\text { Наташа } \\
\text { Станковић Шошо }\end{array}$ & 13. 7. 2017. \\
\hline & $\begin{array}{l}\text { Наративне } \\
\text { стратегије и } \\
\text { историјски и } \\
\text { митолошки елменти } \\
\text { у светлу трагичних } \\
\text { повести Андрићевог } \\
\text { романа „На Дрини } \\
\text { ћуприја” }\end{array}$ & Ивана Муњић & $\begin{array}{l}\text { Зона Мркаљ, } \\
\text { Наташа } \\
\text { Станковић Шошо }\end{array}$ & 13. 7. 2017. \\
\hline & $\begin{array}{l}\text { Књижевно дело } \\
\text { Исидоре Секулић у } \\
\text { настави }\end{array}$ & Ана Козић & $\begin{array}{l}\text { Наташа } \\
\text { Станковић Шошо, } \\
\text { Љиљана Бајић, }\end{array}$ & 29. 9. 2017. \\
\hline & $\begin{array}{l}\text { Обрада романа } \\
\text { „Аутобиографија” } \\
\text { Бранислава Нушића }\end{array}$ & $\begin{array}{l}\text { Марина } \\
\text { Јовановић }\end{array}$ & $\begin{array}{l}\text { Наташа } \\
\text { Станковић Шошо, } \\
\text { Љиљана Бајић, }\end{array}$ & 29.9. 2017. \\
\hline & $\begin{array}{l}\text { Специфичности } \\
\text { приступа делу Симе } \\
\text { Матавуља у настави } \\
\text { српског језика и } \\
\text { књижевности }\end{array}$ & Жељана Вуканац & $\begin{array}{l}\text { Зона Мркаљ, } \\
\text { Наташа } \\
\text { Станковић Шошо }\end{array}$ & 30.9. 2017. \\
\hline 2018. & $\begin{array}{l}\text { Мотивисање } \\
\text { ученика за читање } \\
\text { и тумачење } \\
\text { књижевног дела } \\
\text { Борислава Пекића }\end{array}$ & Невена Бужек & $\begin{array}{l}\text { Зона Мркаљ, } \\
\text {, Наташа } \\
\text { Станковић Шошо }\end{array}$ & 31. 1. 2018. \\
\hline & $\begin{array}{l}\text { Посебности } \\
\text { наставног } \\
\text { проучавања народне } \\
\text { и ауторске бајке на } \\
\text { примеру народних } \\
\text { бајки „Пепељуга” и } \\
\text { „Царево ново одело, }\end{array}$ & Марија Ђорђевић & $\begin{array}{l}\text { Зона Мркаљ, } \\
\text { Наташа } \\
\text { Станковић Шошо }\end{array}$ & 14. 2. 2018 . \\
\hline & $\begin{array}{l}\text { Нови поглед на } \\
\text { корелације у настави } \\
\text { српског језика и } \\
\text { књижевности }\end{array}$ & Љубица Георгијев & $\begin{array}{l}\text { Зона Мркаљ, } \\
\text { Наташа } \\
\text { Станковић Шошо }\end{array}$ & 4. 7. 2018 . \\
\hline
\end{tabular}




\begin{tabular}{|c|c|c|c|c|}
\hline & $\begin{array}{l}\text { Наставна обрада } \\
\text { лирске песме „Сума- } \\
\text { тра” М. Црњанског и } \\
\text { њен књижевноисто- } \\
\text { ријски контекст }\end{array}$ & Бојан Гојковић & $\begin{array}{l}\text { Зона Мркаљ, } \\
\text { Наташа } \\
\text { Станковић Шошо }\end{array}$ & 27. 9. 2018. \\
\hline \multirow[t]{5}{*}{2019.} & $\begin{array}{l}\text { Мултимедијалне } \\
\text { технологије и ин- } \\
\text { тернет у функцији } \\
\text { мотивисања ученика } \\
\text { за проучавање књи- } \\
\text { жевноуметничких } \\
\text { текстова }\end{array}$ & Ирена Манић & $\begin{array}{l}\text { Наташа } \\
\text { Станковић Шошо, } \\
\text { Љиљана Бајић }\end{array}$ & 12. 6. 2019 . \\
\hline & $\begin{array}{l}\text { Методичка } \\
\text { припрема за } \\
\text { обраду „Сеоба” } \\
\text { М. Црњанског у } \\
\text { средњој школи }\end{array}$ & $\begin{array}{l}\text { Кристина } \\
\text { Петровић }\end{array}$ & $\begin{array}{l}\text { Наташа } \\
\text { Станковић Шошо, } \\
\text { Љиљана Бајић }\end{array}$ & 17. 6. 2019 . \\
\hline & $\begin{array}{l}\text { Стваралаштво } \\
\text { Милоша Црњанског } \\
\text { у средњошколској } \\
\text { настави }\end{array}$ & $\begin{array}{l}\text { Емилија } \\
\text { Пандоски }\end{array}$ & $\begin{array}{l}\text { Наташа } \\
\text { Станковић Шошо, } \\
\text { Љиљана Бајић }\end{array}$ & 12. 7. 2019. \\
\hline & $\begin{array}{l}\text { Методички } \\
\text { поступци у } \\
\text { наставном } \\
\text { проучавању } \\
\text { драмских текстова }\end{array}$ & $\begin{array}{l}\text { Јасмина } \\
\text { Анђелковић }\end{array}$ & $\begin{array}{l}\text { Наташа } \\
\text { Станковић Шошо, } \\
\text { Љиљана Бајић }\end{array}$ & 4. 9. 2019. \\
\hline & $\begin{array}{l}\text { Анализа } \\
\text { инклузивног } \\
\text { поступка у шестом } \\
\text { разреду основне } \\
\text { школе }\end{array}$ & Ивана Пантелић & $\begin{array}{l}\text { Зона Мркаљ, } \\
\text { Наташа } \\
\text { Станковић Шошо }\end{array}$ & 6. 9. 2019. \\
\hline
\end{tabular}

На основу табеларног приказа може се закључити да је највише радова посвећено наставном проучавању књижевних текстова из Српске књижевности 20. века (13 радова) и Српске књижевности 18. и 19. века (5 радова). Наставној обради ауторских бајки (Х. К. Андерсен, Г. Олуји, Т. Тосић) посвећена су три рада, а обради народне књижевности два рада. Од укупно 8 радова, примену мултимедијалних садржаја у настави анализирају 3 рада, проблеме инклузије у савременој школи 2 рада, наставне корелације 1 рад, организацији рада новинарске секције 1 рад и настави креативног писања 1 рад.

Студенти Српске књижевности и језика и Српске књижевности и језика са компаратистиком на основним и мастер академ- 
ским студијама стичу базична професионална искуства о наставној теорији и пракси у области књижевности, језика и језичког изражавања, што ће им бити ваљана основа за даљи развој професионалних компетенција и професионално бављење књижевношћу и језиком у основношколском и средњошколском образовању.

\section{Методика наставе српског језика и књижевности на Ка- тедри за српски језик са јужнословенским језицима Фи- лолошког факултета у Београду}

На Катедри за српски језик са јужнословенским језицима методичке предмете данас предају непосредни наследници проф. др Милорада Дешића, проф. др Вељко Брборић, проф. др Драгана Вељковић Станковић и асистент мср Валентина Илић. У Табели 5 представићемо све методичке курсеве са основних студија Српски језик и књижевност (студијска група 01, наставнички профил) и мастер студија Српски језик (наставнички профил).

Табела 5: Методички предмети на основним и мастер академским студијама на Катедри за српски језик са јужнословенским језицима

\begin{tabular}{|c|c|c|c|c|c|c|}
\hline \multirow[b]{2}{*}{$\begin{array}{c}\text { Ниво } \\
\text { студија }\end{array}$} & \multicolumn{5}{|c|}{ OAC } & \multirow{2}{*}{$\begin{array}{c}\text { МАС } \\
\text { V година } \\
\text { (9. семес- } \\
\text { тар) } \\
\end{array}$} \\
\hline & $\begin{array}{c}\text { III година } \\
\text { (5. семес- } \\
\text { тар) }\end{array}$ & $\begin{array}{c}\text { III година } \\
\text { (6. семес- } \\
\text { тар) }\end{array}$ & $\begin{array}{l}\text { IV година } \\
\text { (7. семес- } \\
\text { тар) }\end{array}$ & $\begin{array}{l}\text { IV година } \\
\text { (8. семес- } \\
\text { тар) }\end{array}$ & $\begin{array}{l}\text { IV година } \\
\text { (8. семес- } \\
\text { тар) }\end{array}$ & \\
\hline $\begin{array}{c}\text { Назив } \\
\text { предмета }\end{array}$ & 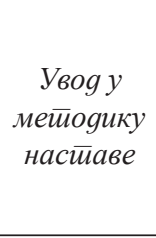 & 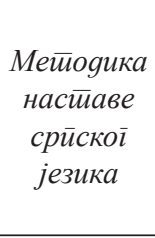 & 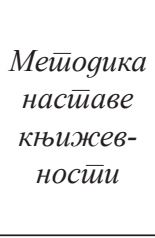 & 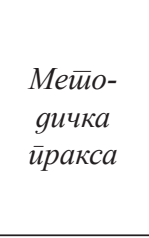 & 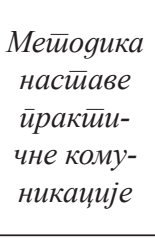 & 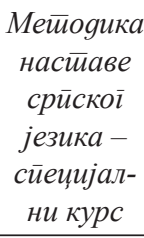 \\
\hline $\begin{array}{c}\text { Статус } \\
\text { предмета }\end{array}$ & обавезан & обавезан & обавезан & обавезан & изборни & обавезан \\
\hline $\begin{array}{c}\text { Тип } \\
\text { предмета }\end{array}$ & $\mathrm{CA}^{*}$ & CA & $\mathrm{CA}$ & CA & CA & CA \\
\hline $\begin{array}{c}\text { Број } \\
\text { часова } \\
\text { недељно }\end{array}$ & $\begin{array}{c}\text { Преда- } \\
\text { вања (П): } \\
2 \text { часа } \\
\text { Вежбања } \\
\text { (В): } 2 \text { часа }\end{array}$ & $\begin{array}{l}\text { П: } 2 \text { часа } \\
\text { В: } 2 \text { часа }\end{array}$ & $\begin{array}{l}\text { П: } 2 \text { часа } \\
\text { В: } 2 \text { часа }\end{array}$ & $\begin{array}{c}\text { П: } 2 \text { часа } \\
\text { В: } 0 \text { ча- } \\
\text { сова }\end{array}$ & $\begin{array}{c}\text { П: } 2 \text { часа } \\
\text { В: } 0 \text { ча- } \\
\text { сова }\end{array}$ & $\begin{array}{l}\text { П: } 2 \text { часа } \\
\text { В: } 2 \text { часа }\end{array}$ \\
\hline
\end{tabular}




\begin{tabular}{|c|c|c|c|c|c|c|}
\hline $\begin{array}{c}\text { Број } \\
\text { бодова }\end{array}$ & 6 ЕСПБ & 6 ЕСПБ & 6 ЕСПБ & 6 ЕСПБ & 3 ЕСПБ & 6 ЕСПБ \\
\hline Предавачи & $\begin{array}{l}\text { П: проф. } \\
\text { др Вељко } \\
\text { Брборић, } \\
\text { проф. др } \\
\text { Драгана } \\
\text { Вељковић } \\
\text { Станко- } \\
\text { вић; } \\
\text { В: мср Ва- } \\
\text { лентина } \\
\text { Илић }\end{array}$ & $\begin{array}{l}\text { П: проф. } \\
\text { др Вељко } \\
\text { Брборић, } \\
\text { В: проф. } \\
\text { др Дра- } \\
\text { гана } \\
\text { Вељковић } \\
\text { Станко- } \\
\text { вић, мср } \\
\text { Валенти- } \\
\text { на Илић }\end{array}$ & $\begin{array}{l}\text { П: проф. } \\
\text { др Вељко } \\
\text { Брборић, } \\
\text { В: проф. } \\
\text { др Драга- } \\
\text { на Вељко- } \\
\text { вић Стан- } \\
\text { ковић, } \\
\text { мср Ва- } \\
\text { лентина } \\
\text { Илић }\end{array}$ & $\begin{array}{l}\text { Проф. др } \\
\text { Вељко } \\
\text { Брборић, } \\
\text { проф. др } \\
\text { Драгана } \\
\text { Вељковић } \\
\text { Станко- } \\
\text { вић, мср } \\
\text { Валенти- } \\
\text { на Илић }\end{array}$ & $\begin{array}{l}\text { П: проф. } \\
\text { др Драга- } \\
\text { на Вељко- } \\
\text { вић Стан- } \\
\text { ковић, } \\
\text { мср Ва- } \\
\text { лентина } \\
\text { Илић }\end{array}$ & $\begin{array}{l}\text { П: проф. } \\
\text { др Драга- } \\
\text { на Вељко- } \\
\text { вић Стан- } \\
\text { ковић; } \\
\text { В: мср Ва- } \\
\text { лентина } \\
\text { Илић }\end{array}$ \\
\hline
\end{tabular}

*CA - стручно-апликативни

Прва три наведена курса (Увод у методику наставе, Методика наставе српског језика и Методика наставе књижевности) организовани су према сличном принципу, садржајима и циљевима и задацима наставе који су описани у претходном поглављу и односе се на изучавање Методике на Катедри за српску књижевност. Наиме, студенти се упознају са методиком као аутономном научном дисциплином, утемељеном у знањима науке о језику и науке о књижевности, а која је комплементарна са другим наукама: педагогијом, дидактиком, психологијом, психолингвистиком, филозофијом, социологијом и др., које се у литератури називају кореспондирајућим (Илић 1997: 19), односно граничним наукама (Милатовић 2019: 20). Током ова три теоријска курса, на којима похађају и часове вежбања, студенти се тако упознају са ширином, озбиљношћу али и посебношћу наставничког позива, а истовремено се припремају за практичну методику - писање наставне припреме и реализацију самосталног испитног часа у основној или средњој школи. ${ }^{5}$

5 Зато на овом месту нећемо детаљније описивати курсеве Увод у методику наставе, Методику наставе српског језика и Методику наставе книжевности, будући да су истоимени курсеви већ описани у првом делу рада, а на Катедри за српски језик они имају сличан садржај, циљеве и исходе. Тако ћемо избећи непотребна понављања. Задржаћемо се само на Методичко пракси, Методици наставе практичне комуникације и Методици наставе српског језика са мастер програма. 
МЕТОДИЧКА ПРАКСА НА ОСНОВНИМ СТУДИЈАМА СРПСКОГ ЈЕЗИКА И КњИЖЕВНОСТИ НА ФИЛОЛОШКОМ ФАКУЛТЕТУ УНИВЕРЗИТЕТА У БЕогРАду. Будући да се Методичка пракса највећим делом реализује у школама, овај испит не може пратити редовну динамику факултетских испитних рокова. ${ }^{6}$ На четвртој години студија студенти се почетком пролећа пријављују за полагање Методичке праксе, која се реализује у летњем семестру. Готово читава генерација студената тада полаже овај предмет. Други рок за хоспитовање постоји и у зимском семестру, међутим, тада се по правилу пријави мањи број студената који су из неког разлога пропустили боравак у школи током летњег семестра.

Већ дуги низ година студенти се распоређују за хоспитовање у четири београдске школе са којима методичари са Катедре за српски језик веома успешно сарађују. То су ОШ „Браћа Барух” на Дорћолу, ОШ „Иван Гундулић” на Новом Београду, Девета београдска гимназија „Михаило Петровић - Алас” на Новом Београду и Фармацеутско-физиотерапеутска средња школа на Звездари. ${ }^{7}$

О ЕТАПАМА И САДРЖАЈУ МЕТОДИЧКЕ ПРАКСЕ. НаКОН ПријављИвања за полагање овог испита студенти се распоређују у групе од по 8 до 10 студената. За сваку групу одређује се (1) датум и време одласка у школу, (2) датум предаје припреме за држање часа и (3) датум реализације наставне јединице. На часу реализације сваки студент се обавештава о (4) датуму предаје Извештаја (дневника) хоспитовања. Сваку од наведених етапа (1-4) образложићемо У даљем тексту.

1) БоРАВАК У Школи. Група студената одлази у једну од предвиђених школа у заказаном термину. У школи их дочекују професори српског језика који их воде кроз хоспитовање и упућују их

6 Током јануарског и фебруарског рока није функционално одлазити у школе због зимског распуста; за време јунског и јулског рока почиње, односно траје школски летњи распуст. У јесењем испитним роковима, у септембру, тек је почетак школске године, па ни тада није згодно оптеретити тек почелу школску наставу студентским боравком и полагањем испита.

7 Професори српског језика који у школама годинама дочекују наше студенте су: др Милица Томовић (ОШ „Браћа Барух”), Радмила Орељ и Сузана Кићановић (ОШ „Иван Гундулић”), Невена Грујичић, Миланка Ршумовић и Милорад Дашић (Девета београдска гимназија „Михаило Петровић - Алас”) и Јелена Стојиљковић (Фармацеутско-физиотерапеутска школа). 
на наставничке обавезе. Студенти тамо проведу неколико дана током којих траје опсервација десетак часова Српског језика и књижевности. Наставници се труде да за то време они одслушају часове у различитим разредима и одељењима (у основној школи, од 5. до 8. разреда; у средњој школи, од 1. до 4. разреда), и то часове са свих наставних подручја: језика (граматике), књижевности и језичке културе. Том приликом студенти углавном испрате часове обраде новог градива или комбиновани тип часа. Током часова опсервације они уочавају наставникове методичке поступке и приступе, методе и принципе, облике рада, организацију часа, представљање и тумачење градива, навођење примера или ток интерпретације књижевноуметничког текста, као и однос према ученицима, атмосферу на часу и, истовремено, однос ученика према настави и наставнику. Сва запажања бележе у дневник који воде током целокупног хоспитовања. Труде се да упореде теоријска методичка знања са конкретним практичним приступима и ситуацијом у учионици: да ли наставници одступају од неких методичких начела, када и због чега, како се сналазе у непредвиђеним околностима и др. Такође, упоређују обраду исте наставне јединице у различитим одељењима, али и приступе у млађим и старијим разредима. Поред опсервације часова, наставници окупљеним студентима показују школску документацију, традиционалне и електронске дневнике, начин њиховог попуњавања, као и наставне програме и наставна средства. Тада сваком студенту додељују наставну јединицу из области језика или књижевности коју ће имати за обраду на испитном часу.

2) ПРИПРЕМА ЗА РЕАЛИЗАЦИЈУ НАСТАВНЕ ЈЕДИНИЦЕ. ПОШТО су завршени часови опсервације, студенти се посвећују писању своје методичке припреме. Она за потребе овог предмета има устаљену структуру, са којом се кандидати детаљно упознају на неколико часова вежбања уочи хоспитовања:

- Насловна страна (садржи афилијацију, назив предмета, наслов наставне јединице (нпр. Синтагма - појам и врсте); име и презиме ментора и кандидата, место и годину предаје рада);

- Општи подаци о држању часа (подразумевају назив и адресу школе, наставни предмет, разред и одељење, име и презиме 
предметног наставника, датум и време држања часа, наставну јединицу, тип часа, облике рада, наставне методе и наставна средства);

- Литература за ученике и литература за наставнике (стручна и методичка); нални);

- Наставни циљеви часа (образовни, васпитни и функцио-

- Истраживачки задаци (ако их има);

- Временска артикулација часа (уводног, главног и завршног дела);

- Разрада тока часа (Сегментирана је на уводни, главни и завршни део часа. Сваки од њих се планира до детаља, па припрема има структуру: питање - очекивани одговор. У њој студенти показују како тумаче и обрађују дату наставну јединицу, примењујући стечена теоријска методичка и стручна знања током студија. У уводном делу часа ученике мотивишу за обраду нове наставне јединице, обнављају са њима позната знања која су са њом у непосредној и тесној вези; у главном делу труде се да обраду испланирају поступно и систематично, као и да јасним, директним и несугестивним питањима и налозима ангажују ученичку мисао и активирају их у оптималној мери. У случају наставне јединице из књижевности труде се да открију и анализирају тематскомотивске, композицијске, језичко-стилске и идејне слојеве дела, док у случају обраде јединице из језика настоје да уз репрезентативне примере и њихову анализу осмисле и довољан број задатака за вежбање. У завршном делу часа стечена знања се сумирају и уопштавају, односно увежбавају.)

- Прилози (наставни листићи са решењима; илустрације и други радни материјал);

- Скица изгледа табле на крају часа.

Овако структурирану наставну припрему студенти предају професору на Катедри, а затим на наредном, заказаном часу консултација добијају повратне информације у вези са њеним квалитетом и сугестије за евентуалну поправку, дораду или реорганизацију, уз још неколико неопходних практичних савета за њену реализацију. Студенти по потреби, у договору са наставником из школе, односе истраживачке задатке оним одељењима у 
којима полажу испит. На часу консултација професор студентима одговара на сва додатна питања и пружа им неопходну подршку, будући да студенти неретко имају трему и страх од јавног наступа пред ученицима и професорима и истовремено испитне ситуације, што за њих није нимало лак задатак.

3) ДРЖАњЕ испитног чАСА. Најважнију етапу Методичке праксе чини реализација наставне јединице. Студент је ту први пут у улози наставника српског језика и књижевности. Час држи у одељењу пред двочланом комисијом, коју чини професор српског језика из школе и један од методичара (професори или асистент) са Катедре за српски језик. Чланови комисије прате реализацију припреме коју је студент предао, посматрају његов однос према ученицима, спонтано сналажење у различитим наставним ситуацијама, владање градивом, начин одговарања на постављена ученичка питања, усаглашеност реализације са временом које се има на располагању и др. Комисија води рачуна да кандидат не прави материјалне грешке. Такође, веома је важно да припрема буде реализована у највећој могућој мери и да студент уђе у завршни део пре завршетка часа. Нетачно представљање или тумачење градива и несналажење са временом, односно нереализовање наставне јединице за време испитног часа дисквалификују кандидата. Дешава се понекад да студенти са не тако сјајним припремама одрже веома успешан час, али и супротно, да се студенти који осмисле одличну припрему не снађу са њеном реализацијом, те час тако остане монотон, не високо ефективан и отуда просечан. То упућује на позитиван утицај даровитости на обављање наставничког позива: јасност, гласност, динамичност, прецизност, одмереност, стрпљивост и благонаклоност јесу само неке од особина које подржавају висок квалитет наставе. Након одржаног часа, чланови комисије разговарају са кандидатом, коментаришући добре и лоше стране реализације (уколико их има), дајући му корисна запажања и смернице за будући рад.

4) ИЗВЕшТАЈ СА ХоспитовАњА. Последња етапа Подразумева писање и предају извештаја (тзв. дневника хоспитовања). Студенти су унапред упознати са његовом структуром и већ га имају у виду обрасца који треба попунити. Састоји се од три дела: 
1. Списак часова којима су присуствовали, битна запажања, гледишта и размишљања о боравку у школи, тј. о обављеној пракси и узимању наставне јединице;

2. Запажања о садржајима уводног, главног и завршног дела одржаног часа и

3. Остала битна запажања, гледишта и размишљања поводом одржаног часа и боравка у школи.

O попуњавању првог сегмента водили су рачуна током часова опсервације, када воде белешке, које уносе и разрађују потом у овом извештају. Други и трећи сегмент обрасца попуњавају након одржаног часа, односно завршеног боравка у школи. Упућују се да том приликом критички сагледају своју реализацију и истакну њене позитивне и негативне стране, (не)остварена очекивања, као и могућности за њену успешнију разраду, ако сматрају да их има. Укупне утиске и примедбе са Методичке праксе студенти износе у трећем делу извештаја. Многи од њих у њима исказују потребу за већим бројем часова хоспитовања, описују лепе и импресивне тренутке проведене у школи, а понеко и истакне да је то једини позив којим жели да се бави. Тако, на пример, једна студенткиња наводи: „Сам боравак у школи, а нарочито држање мог првог часа, представљају незаборавно искуство”, друга истиче: „Ово је било драгоцено искуство [које] ми је помогло да први пут сагледам час из перспективе професора”, а трећа, образлажући драгоценост тог искуства, додаје: „Улило ми је наду, пробудило ентузијазам и подсетило ме који су то идеали и циљеви које сам себи поставила и којима стремим". Већина студентских извештаја садржи оваква запажања. Она су доказ важности и утилитарности овог предмета, који подсећа студенте да је учионица простор ведрине и позитивне енергије, место на коме наши студенти желе да буду и које им иманентно припада.

По завршетку последње етапе Методичке праксе студентима се своде коначне оцене, које се састоје од средње вредности оцена предате припреме, затим њене коначне, побољшане верзије, реализације часа и написаног извештаја.

МЕТОДИКА НАСТАВЕ ПРАКТИЧНЕ КОМУНИКАЦИЈЕ - ИЗБОРНИ кУРс. Овај предмет могу изабрати студенти у осмом семестру 
студија заинтересовани за проширивање методичких знања увођењем комуникативног приступа у наставу кроз примену прагматичких и комуниколошких знања и достигнућа, кооперативног принципа, Грајсових максима и теорије релеванције, као и језика савремених медија, који се могу на различите креативне начине - у виду мотивацијског фактора, наставног материјала и сл. - укључити у методичке моделе. Њихова примена омогућава ефикасније и функционалније овладавање градивом из језика и брже активирање ових знања у различитим комуникативним ситуацијама. Студенти се оспособљавају за осмишљавање подстицајних и иновативних методичких приступа, који код ученика развијају језичку компетенцију, различита сазнања о вербалној и невербалној комуникацији, културу усменог и писменог изражавања, културу слушања, а који су неретко засновани на мултидисиплинарним приступима и савременој технологији.

МЕТОДИКА НАСТАВЕ СРПСКОГ ЈЕЗИКА НА МАСТЕР СТУДИЈАМА. На мастер студијском модулу Српски језик предмет Методика наставе српског језика - спещијални курс обавезан је за све студенте наставничког профила. Током семестра слушају два часа предавања и два часа вежбања недељно, на којима се усмеравају и припремају за лингвистичка истраживања која се инкорпорирају у часове додатне наставе или лингвистичке секције. На крају овога курса студент је у обавези да напише семинарски рад који представља методички модел од три до пет часова који се могу реализовати у трећем или четвртом разреду гимназије на овим додатним часовима намењеним надареним ученицима. У том раду студенти уз примену креативних и савремених методичких приступа, облика рада и наставних средстава повезују позната знања са новим, модернијим или непознатим научним датостима и струјањима, уобличавају неко сопствено лингвистичко истраживање које подразумева познате језичке појаве, али истражене на новом корпусу, који може припадати разним функционалним стиловима. Тако се неретко циљеви модела односе на повезивање наставе граматике, лексикологије и стилистике са наставом књижевности, уз осветљавање функција различитих језичко-стилских аспеката у књижевноуметничком тексту, од- 
носно у ширем опусу неког писца. Поједини методички приступи усмерени су на проширивање активног и пасивног вокабулара ученика, развој културе усменог и писменог изражавања и функционалне и медијске писмености. Негује се проблемски приступ у настави језика и виши степен индивидуализације наставе. Често се планира примена великих дескриптивних речника, али и других, специјалних - речника жаргона, синонима, етимолошког или асоцијативног речника. У наставу се укључује и Вуков Српски рјечник, нарочито у сврху упознавања са Вуковим лексикографским поступцима, али и значењима појединих лексема и њиховим лингвокултуролошким семантичким наносима. Фрагменти традиционалне културе реконструишу се и на основу корпуса народних песама, па се на тај начин откривају бројни културолошки, друштвени, економски и други чиниоци наше прошлости и истовремено успоставља корелација са другим наставним предметима. Сваки методички модел по правилу прати и Power Point презентација намењена ученицима, па се на тај начин у наставу укључују и мултимедијална средства. Током писања овог семинарског рада студенти се усмеравају да самостално проналазе неопходну ужу и ширу литературу и да на основу досадашњег искуства селектују релевантне референце за своју област, тему и предмет истраживања. Уз то, паралелно се оспособљавају и увежбавају да овај мали научно-стручни рад технички уобличе према правилима академског писања, чиме се непосредно припремају за писање мастер рада и других научних текстова.

ЗАВРШНИ (МАСТЕР) РАДОВИ ИЗ МЕТОДИКЕ НАСТАВЕ СРПСКОГ ЈЕЗиКА. Студенти чија су интересовања највише усмерена на наставу за област завршног (мастер) истраживања најчешће бирају Методику. Ова апликативна дисциплина им омогућава да на различите, иновативне и креативне начине обликују језичка знања која су намењена за „поход у свест ученика”, истовремено укључујући како предметна, тако и ванпредметна знања (педагошка, психолошка, социолошка и др.). У мастер тезама студенти се усмеравају на једну језичку област коју посебно истражују, уочавајући јаче и слабије стране ученичких постигнућа. У наредној табели даћемо приказ тема мастер радова, њихових аутора, чла- 
нова комисије и датума када су одбрањени, у периоду 2014-2019. године.

Табела 6: Одбрањени Завршни мастер радови из

Методике наставе српског језика (2014-2019)

\begin{tabular}{|c|c|c|c|c|}
\hline & Наслов рада & Кандидат & $\begin{array}{c}\text { Комисија } \\
\text { (ментор и члан) }\end{array}$ & $\begin{array}{c}\text { Датум } \\
\text { одбране } \\
\end{array}$ \\
\hline \multirow[t]{5}{*}{2014.} & $\begin{array}{l}\text { Интерпункција у } \\
\text { основној школи (две } \\
\text { смедеревске школе) }\end{array}$ & Олга Терзић & $\begin{array}{l}\text { Вељко Брборић, } \\
\text { Рајна Драгићевић }\end{array}$ & 17. 7. 2014. \\
\hline & $\begin{array}{l}\text { Правопис на прелазу } \\
\text { из млађих у старије } \\
\text { разреде основне школе }\end{array}$ & Цица Бацић & $\begin{array}{l}\text { Вељко Брборић, } \\
\text { Рајна Драгићевић }\end{array}$ & 17. 7. 2014. \\
\hline & $\begin{array}{l}\text { Настава падежа у дија- } \\
\text { лекатској средини }\end{array}$ & $\begin{array}{l}\text { Емилија } \\
\text { Васиљевић }\end{array}$ & $\begin{array}{l}\text { Вељко Брборић, } \\
\text { Милан Стакић }\end{array}$ & 24. 9. 2014 . \\
\hline & $\begin{array}{l}\text { Писање скраћеница у } \\
\text { средњој школи (гимна- } \\
\text { зија у Београду и гима- } \\
\text { зија у Александровцу) }\end{array}$ & $\begin{array}{l}\text { Ангелина } \\
\text { Кршанин }\end{array}$ & $\begin{array}{l}\text { Вељко Брборић, } \\
\text { Рајна Драгићевић }\end{array}$ & 9. 10. 2014. \\
\hline & $\begin{array}{l}\text { Настава глаголског } \\
\text { система у основној } \\
\text { школи }\end{array}$ & $\begin{array}{l}\text { Јасмина } \\
\text { Стојановић }\end{array}$ & $\begin{array}{l}\text { Вељко Брборић, } \\
\text { Рајна Драгићевић }\end{array}$ & 9. 10. 2014. \\
\hline \multirow[t]{4}{*}{2015.} & $\begin{array}{l}\text { Правописни дублети у } \\
\text { наставној пракси }\end{array}$ & $\begin{array}{l}\text { Сања } \\
\text { Вилотијевић }\end{array}$ & $\begin{array}{l}\text { Вељко Брборић, } \\
\text { Рајна Драгићевић }\end{array}$ & 10.2. 2015 \\
\hline & $\begin{array}{l}\text { Спојено и одвојено пи- } \\
\text { сање речи у наставној } \\
\text { пракси: средња школа }\end{array}$ & $\begin{array}{l}\text { Катарина } \\
\text { Ивановић }\end{array}$ & $\begin{array}{l}\text { Вељко Брборић, } \\
\text { Рајна Драгићевић }\end{array}$ & 14. 9. 2015. \\
\hline & $\begin{array}{l}\text { Писање великог и } \\
\text { малог слова у основ- } \\
\text { ној школи (основне } \\
\text { школе у Бабушници и } \\
\text { Звонцу) }\end{array}$ & $\begin{array}{l}\text { Љубица } \\
\text { Стојановић }\end{array}$ & $\begin{array}{l}\text { Вељко Брборић, } \\
\text { Милан Стакић }\end{array}$ & 14. 9. 2015. \\
\hline & $\begin{array}{l}\text { Утицај савремених ме- } \\
\text { дија на наставу српског } \\
\text { језика и књижевности } \\
\text { (у основној школи) }\end{array}$ & $\begin{array}{l}\text { Марија } \\
\text { Качаревић }\end{array}$ & $\begin{array}{l}\text { Вељко Брборић, } \\
\text { Драгана Вељковић } \\
\text { Станковић }\end{array}$ & 30. 12. 2015. \\
\hline \multirow[t]{2}{*}{2016.} & $\begin{array}{l}\text { Састављено и раста- } \\
\text { вљено писање именица } \\
\text { у средњој школи }\end{array}$ & $\begin{array}{l}\text { Александра } \\
\text { Станковић }\end{array}$ & $\begin{array}{l}\text { Вељко Брборић, } \\
\text { Александар } \\
\text { Милановић }\end{array}$ & 28. 1. 2016 . \\
\hline & $\begin{array}{l}\text { Гласовне алтернације у } \\
\text { средњој школи }\end{array}$ & Ненад Мирић & $\begin{array}{l}\text { Вељко Брборић, } \\
\text { Александар } \\
\text { Милановић }\end{array}$ & 12. 2. 2016 . \\
\hline
\end{tabular}




\begin{tabular}{|c|c|c|c|c|}
\hline & $\begin{array}{l}\text { Употреба помоћних } \\
\text { интерпункцијских } \\
\text { знакова код средњош- } \\
\text { колаца }\end{array}$ & $\begin{array}{l}\text { Лидија } \\
\text { Марковић }\end{array}$ & $\begin{array}{l}\text { Вељко Брборић, } \\
\text { Александар } \\
\text { Милановић }\end{array}$ & 6.9. 2016. \\
\hline & $\begin{array}{l}\text { Писање скраћеница } \\
\text { у основној и средњој } \\
\text { школи (основне школе } \\
\text { и гимназије у Пожеги } \\
\text { и у Београду) }\end{array}$ & Нада Бабић & $\begin{array}{l}\text { Вељко Брборић, } \\
\text { Драгана Вељковић } \\
\text { Станковић }\end{array}$ & 20.9. 2016 . \\
\hline & $\begin{array}{l}\text { Облици припрема за } \\
\text { писање писмених зада- } \\
\text { така у вишим разреди- } \\
\text { ма основне школе }\end{array}$ & Милица Рајачић & $\begin{array}{l}\text { Драгана Вељковић } \\
\text { Станковић, } \\
\text { Вељко Брборић }\end{array}$ & 29. 9. 2016 . \\
\hline & $\begin{array}{l}\text { Креативни приступ } \\
\text { обради романа И. } \\
\text { Андрића „Проклета } \\
\text { авлија” у средњој } \\
\text { школи }\end{array}$ & $\begin{array}{l}\text { Оливера } \\
\text { Настевска }\end{array}$ & $\begin{array}{l}\text { Драгана Вељковић } \\
\text { Станковић }\end{array}$ & 30. 9. 2016. \\
\hline & $\begin{array}{l}\text { Фонетика и фоноло- } \\
\text { гија српског језика у } \\
\text { наставној пракси }\end{array}$ & $\begin{array}{l}\text { Милица } \\
\text { Велимановић }\end{array}$ & $\begin{array}{l}\text { Вељко Брборић, } \\
\text { Драгана Вељковић } \\
\text { Станковић }\end{array}$ & 6. 10. 2016 . \\
\hline & $\begin{array}{l}\text { Методички приступи } \\
\text { усвајању лексике тра- } \\
\text { диционалне културе у } \\
\text { средњој школи }\end{array}$ & $\begin{array}{l}\text { Александра } \\
\text { Петровић }\end{array}$ & $\begin{array}{l}\text { Драгана Вељковић } \\
\text { Станковић, } \\
\text { Михаило } \\
\text { Шћепановић }\end{array}$ & 28. 12. 2016. \\
\hline \multirow[t]{3}{*}{2017.} & $\begin{array}{l}\text { Глаголски вид и гла- } \\
\text { голски облици у основ- } \\
\text { ношколској пракси }\end{array}$ & Невена Крстић & $\begin{array}{l}\text { Милан Стакић, } \\
\text { Михаило } \\
\text { Шћепановић }\end{array}$ & 8. 5. 2017. \\
\hline & $\begin{array}{l}\text { Писање скраћеница у } \\
\text { основној школи (ОШ } \\
\text { „22. октобар” у Београ- } \\
\text { ду, ОШ „Душан Јерко- } \\
\text { вић” у Ужицу) }\end{array}$ & Татјана Јелић & $\begin{array}{l}\text { Вељко Брборић, } \\
\text { Михаило } \\
\text { Шћепановић }\end{array}$ & 26. 9. 2017. \\
\hline & $\begin{array}{l}\text { Спојено и одвојено пи- } \\
\text { сање именица и приде- } \\
\text { ва у основној школи }\end{array}$ & $\begin{array}{l}\text { Тијана } \\
\text { Обрадовић }\end{array}$ & $\begin{array}{l}\text { Вељко Брборић, } \\
\text { Александар } \\
\text { Милановић }\end{array}$ & 30. 9. 2017. \\
\hline \multirow[t]{2}{*}{2018.} & $\begin{array}{l}\text { Глаголски облици у } \\
\text { основној школи: функ- } \\
\text { ција и значење }\end{array}$ & Весна Деврња & $\begin{array}{l}\text { Вељко Брборић, } \\
\text { Александар } \\
\text { Милановић }\end{array}$ & 22. 1. 2018. \\
\hline & $\begin{array}{l}\text { Падежни систем срп- } \\
\text { ског језика у основној } \\
\text { школи }\end{array}$ & Јелена Биљић & $\begin{array}{l}\text { Вељко Брборић, } \\
\text { Валентина Илић }\end{array}$ & 28. 9. 2018. \\
\hline
\end{tabular}




\begin{tabular}{|c|c|c|c|c|}
\hline & $\begin{array}{l}\text { Лингвометодички тек- } \\
\text { стови у уџбеницима из } \\
\text { српског језика за пети } \\
\text { разред }\end{array}$ & $\begin{array}{l}\text { Невена } \\
\text { Јелисавчић }\end{array}$ & $\begin{array}{l}\text { Вељко Брборић, } \\
\text { Валентина Илић }\end{array}$ & 28. 9. 2018. \\
\hline \multirow[t]{3}{*}{2019.} & $\begin{array}{l}\text { Настава придева у } \\
\text { основној школи }\end{array}$ & $\begin{array}{l}\text { Александра } \\
\text { Мандић }\end{array}$ & $\begin{array}{l}\text { Вељко Брборић, } \\
\text { Валентина Илић }\end{array}$ & 15. 7. 2019. \\
\hline & $\begin{array}{l}\text { Методички приступ } \\
\text { путописној прози Иси- } \\
\text { доре Секулић }\end{array}$ & $\begin{array}{l}\text { Катарина } \\
\text { Иванишевић }\end{array}$ & $\begin{array}{l}\text { Драгана Вељковић } \\
\text { Станковић, } \\
\text { Валентина Илић }\end{array}$ & 30. 9. 2019. \\
\hline & $\begin{array}{l}\text { Рад новинарске } \\
\text { секције у основној } \\
\text { школи }\end{array}$ & Оливера Лазић & $\begin{array}{l}\text { Драгана Вељковић } \\
\text { Станковић, } \\
\text { Валентина Илић }\end{array}$ & 30. 9. 2019. \\
\hline
\end{tabular}

Корпус радова показује да су најчешће обрађиване теме из области правописа (интерпункција, велико слово, састављено и растављено писање, правописни дублети, подела речи на крају реда, скраћенице) и морфологије (у којима се истражују познавање и обрада именичког деклинационог система, глаголских облика, глаголског вида, придева и др.). Два рада посвећена су фонетици и фонологији, односно морфофонологији у основној школи. Једно истраживање бави се адвекватношћу лингвометодичких текстова у уџбеницима за 5. разред основне школе, а јављају се и истраживања која су посвећена припреми за писање школских писмених задатака, утицају савремених медија на наставу, лексици традиционалне културе и сл. Одбрањен је и рад који је усмерен на часове планирања, организације и реализације рада новинарске секције у основној школи. Студенти на смеру Српски језик опредељују се и за методичко истраживање у области књижевности, па ћемо тако у корпусу мастер радова пронаћи и радове посвећене наставним приступима Андрићевом роману или путописној прози Исидоре Секулић. Поједина истраживања конципирана су тако да је могућност њихове непосредне практичне примене у настави заправо њихов најважнији резултат (нпр. рад новинарске секције или приступ путописној прози Исидоре Секулић).

У методолошком смислу радови из Методике који се баве анализом ученичких постигнућа из неке граматичке области имају унапред утврђене етапе истраживања. Најпре се сагледава 
статус дате области у наставним програмима, затим у уџбеничкој и приручничкој литератури, а потом се тест-методом мери њено тренутно познавање у одређеним школама. Обично је реч о једној школи у центру (основна или средња школа у Београду) и једној на периферији (школе у унутрашњости Србије). У њима се тестира исти број одељења једног разреда, а потом се резултати пореде и доносе релевантни закључци. Нека истраживања спроводе се само у једној школи, али се у њима разматра и пореди ученичко знање из неке области на почетку и на крају једног образовног циклуса (нпр. у 5. и 8. разреду).

Резултати методичких истраживања не само да нуде реалну слику познавања неких језичких партија него указују и на слабе карике у ланцу наставни програм - уцбеници - настава знање које треба „ојачати”, односно на приступе који би допринели бољем и лакшем овладавању датим градивом. У већини радова изражава се потреба за већим бројем часова граматике и правописа, а сви радови доследно показују недостатност функционалних знања. Подударност ових закључака свакако треба бити нека врста упозорења и путоказа методичарима наставе за спровођење опсежнијих истраживања и разматрање најефективнијих наставних поступака који ће допринети превазилажењу проблема на које је указано на микроплану, а који су, врло вероватно, део тешкоћа наставног макроплана.

$$
* * *
$$

На националним катедрама (на Катедри за српски језик и Катедри за српску књижевност) Филолошког факултета у Београду студенти се стицањем и теоријских и практичних методичких знања на обавезним и изборним методичким курсевима, кроз испитне обавезе, писање семинарских, дипломских и мастер радова, припремају за будући просветни рад. Стичу сазнања о широј методичкој литератури, а својим лингвистичким и књижевним знањима дају нову перспективу и размишљају о различитим путевима њиховог преношења који би обезбедили ученицима поуздана, функционална и трајна знања и вештине из српског језика и књижевности. 


\section{ИЗВОРИ}

Методичке припреме студената за реализовање часова на предмету $M e$ тодичка пракса на Катедри за српски језик са јужнословенским језицима на Филолошком факултету Универзитета у Београду.

Методичке припреме студената за реализовање часова на предмету $M e$ тодичка пракса на Катедри за српску књижевност и језик са јужнословенским књижевностима на Филолошком факултету Универзитета у Београду.

Дипломски радови из Методике наставе књижевности и српског језика на Катедри за српску књижевност и језик са јужнословенским књижевностима на Филолошком факултету Универзитета у Београду.

Семинарски радови из предмета Методика наставе српског језика (сnецијални курс) на мастер студијама Српски језик.

Мастер радови из Методике наставе српског језика одбрањени на Катедри за српски језик са јужнословенским језицима на Филолошком факултету Универзитета у Београду.

Завршни мастер радови из Методике наставе књижевности и српског језика на Катедри за српску књижевност и језик са јужнословенским књижевностима на Филолошком факултету Универзитета у Београду.

Акредитовани програми из Увода у Методику 05, Увода у Методику 06, Методике наставе књижевности, Методике наставе књижевности и српског језика, Методичке праксе 05, Методичке праксе 06 на основним академским студијама и Методике наставе књижевности на мастер академским студијама.

\section{ЦИТИРАНА ЛИТЕРАТУРА}

Бајић 1994: Љиљана Бајић, Методички приступ збирци приповедне прозе, Београд: Завод за уџбенике и наставна средства.

Бајић 2002: Љиљана Бајић, Књижевно дело Борисава Станковића у настави, Београд: Завод за уџбенике и наставна средства, 2002.

Бајић 2004: Љиљана Бајић, Одабране наставне интерпретације (друго издање), Београд: Завод за уџбенике и наставна средства.

Бајић 2008: Љиљана Бајић, Проучавање хумористичке прозе у настави, Београд: Завод за уџбенике.

Брборић 2004: Вељко Брборић, Правопис српског језика у наставној пракси, Београд: Филолошки факултет.

Илић 1997: П. Илић, Српски језик и књижевност у наставној теорији и пракси. Методика наставе, Нови Сад: Прометеј.

Милатовић 2019: Вук Милатовић, Методика наставе српског језика и књижевности (у млађим разредима основне школе), Београд: Учитељски факултет. [Треће, допуњено и прерађено издање.] 
Мркаљ 2008: Зона Мркаљ, Наставно проучавање народних приповедака и предања, Београд: Друштво за српски језик и књижевност Србије.

Мркаљ 2011: Зона Мркаљ, На часовима српског језика и књижевности, Београд : Завод за уџбенике.

Николић 2009: Милија Николић. Методика наставе српског језика и књижевности, Београд: Завод за уџбенике и наставна средства.

Николић 1983: Милија Николић, Настава писмености, Београд: Научна књига.

Павловић 2008: Миодраг Павловић, Припремање наставника и ученика за тумачење књижевних дела, Београд: Завод за уџбенике.

Росандић 2005: Драгутин Росандић, Методика књижевног одгоја, Загреб: Школска књига.

Станковић Шошо 2019: Књижевно дело Бранислава Нушића у настави, Београд: Друштво за српски језик и књижевност Србије.

\section{МЕТОДИКА ПРЕПОДАВАНИЯ СЕРБСКОГО ЯЗЫКА И ЛИТЕРАТУРЫ НА ФИЛОЛОГИЧЕСКОМ ФАКУЛЬТЕТЕ БЕЛГРАДСКОГО УНИВЕРСИТЕТА}

В докладе рассматриваются обязательные университетские дисциплины и курсы по выбору, касающиеся методики преподавания сербского языка и литературы, разработанные на кафедрах сербского языка с южнославянскими языками и сербской литературы с южнославянскими литературами филологического факультета Белградского университета. В работепоказаносовременное состояние обязательных предметов по методике преподавания и предметов по выбору в бакалавриате и магистратуре, доминирующие способы ихизучения и концепции учебных программ.

Ключевые слова: методика преподавания сербского языка и литературы, университетское изучение национальной литературы, бакалавриат и магистратура. 